\title{
PRESENTACIÓN \\ De la pobreza al florecimiento humano: ¿teoría crítica o utopía?
}

\author{
Julio Boltvinik
}

\section{INTRODUCCIÓN}

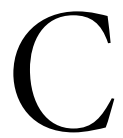

omo resultado de la tesis de doctorado, Ampliar la mirada. Un nuevo enfoque de la pobreza y el florecimiento humano, que presenté en el Centro de Investigaciones y Estudios Superiores en Antropología Social (CIESAS)-Occidente en abril del 2005, recibí la invitación de Virginia García Acosta, directora del CIESAS, y de Jorge Alonso, editor de Desacatos, para preparar un número de esta importante revista con la temática de dicha tesis . Gracias a ambos por la enorme oportunidad para reunir a un grupo tan especial de personas pensantes y críticas y dialogar intensamente con ellas. Después de muchos meses de trabajo de muchas personas (autores, traductores, corrector de estilo, formadora, asistente editorial y editor) se pone a consideración del lector este conjunto de ensayos sobre pobreza, florecimiento humano, teoría crítica y utopía. Los artículos de la sección Saberes y Razones, así como la reseña del libro de Martha Nussbaum, fueron preparados por sus autores a petición mía en un corto periodo, lo que supuso un gran esfuerzo que mucho agradezco. Los artículos (excepto el de Paulette Dieterlen, por tratarse de la discusión del contenido de la revista en su conjunto) fueron sometidos al arbitraje anónimo y en todos los casos añadí mis observaciones a las de los dictámenes, lo que llevó a los autores a realizar cambios que supusieron una tarea adicional de complejidad variable. Mi artículo también constituye un trabajo nuevo. Aunque está basado en mi tesis de doctorado, fui más allá en varios aspectos. También fue sometido al arbitraje anónimo. Agradezco a quienes hicieron los dictámenes sus valiosas observaciones. El número está bellamente ilustrado con fotografías de Rodrigo Moya, tomadas todas ellas de su libro Foto insurrecta. Le agradezco la oportunidad de unir el arte con la reflexión.

El material temático incluido es largo y denso. Cubre un amplio espectro temático de reflexiones que comparten, todas, como preocupación central el futuro de la humanidad. Un material así requiere una

JUlio BOLTVINIK: El Colegio de México, México-Distrito Federal. jbolt@colmex.mx

Desacatos, núm. 23, enero-abril 2007, pp. 13-52. 
presentación que describa con cierto detalle y, sólo sobre esa base, analice, critique, debata y complemente. Está conformada por diez secciones además de esta introducción, ocho referidas a los trabajos publicados. He añadido una para debatir con Ruth Levitas algunas importantes diferencias conceptuales entre ambos, y otra para enriquecer el número con un tema poco analizado en él: las implicaciones de la revolución científico-técnica en la posibilidad del florecimiento humano, incluida después de la presentación del artículo de Araceli Damián.

\section{CRÍTICA DE LA ECONOMÍA POLÍTICA DE LA POBREZA}

Después de esta presentación, el número arranca con mi artículo "Elementos para la crítica de la economía política de la pobreza" (de aquí en adelante referido como Crítica de la EPP). Antes y después de haber presentado mi tesis doctoral formalmente tuve la oportunidad de exponer sus ideas principales en diversos foros. En dichas exposiciones, por razones de tiempo, reduje al mínimo o incluso eliminé la crítica en la que se basan los desarrollos de ésta. Al hacerlo así, varias veces sentí en el auditorio una perplejidad que me hizo recordar un verso de Enrique González Martínez: "El espejo del agua es como una respuesta sin pregunta”. Como a dicho público no le presentaba la crítica, mi propuesta de un enfoque distinto de la pobreza (vinculada al florecimiento humano) parecía, en efecto, una respuesta sin pregunta. Por esta razón decidí en este número de Desacatos presentar una visión del planteamiento de mi tesis centrada en la crítica, aunque incluyendo una visión muy apretada del nuevo enfoque, desarrollado como respuesta al vacío creado por dicha crítica. Ésta pone en evidencia la inadecuación de las respuestas existentes, lo que equivale a la ausencia de una respuesta satisfactoria a la pregunta sobre los elementos constitutivos de los ejes de florecimiento humano y de nivel de vida. El enfoque desarrollado es una respuesta a esta pregunta, pero si se le presenta sin mostrar la inadecuación de las teorías vigentes, la propuesta parece carecer de sentido. A esta crítica la he llamado crítica externa porque se apoya en el nuevo paradigma desarrollado pa- ra identificar las fallas del paradigma anterior, mientras que a la crítica que había venido realizando antes de la tesis, centrada sobre todo en los métodos de medición de la pobreza, la he llamado crítica interna, porque a pesar de haber adoptado una visión más amplia que la usual, me mantenía en el viejo paradigma en un sentido doble: en lo metodológico, porque abordaba el eje del nivel de vida de manera directa, sin derivarlo del eje de florecimiento humano, como se postula en el nuevo paradigma; y en lo sustantivo, porque sostenía como respuesta a la pregunta sobre el elemento constitutivo de ambos ejes la de la satisfacción de necesidades, compartiendo esta esencia con la visión dominante (aunque a partir de una visión más amplia de las necesidades) a la que he llamado el "enfoque convencional de las necesidades" en la sección 6 de Crítica de la EPP. En el nuevo enfoque esta respuesta ha sido sustituida por la de desarrollo de las fuerzas esenciales humanas: necesidades y capacidades, que reemplaza la visión pasiva, de consumidor, del ser humano, por una que integra sus lados activo y pasivo.

No tendría sentido intentar aquí una nueva síntesis del enfoque desarrollado, de por sí ya excesivamente resumido en la sección 2 de Crítica de la EPP. En cuanto a la crítica, se aborda todo el espectro de respuestas a la pregunta sobre el elemento constitutivo del eje del nivel de vida, comenzando con la del utilitarismo, que identifica la utilidad como dicho elemento, siguiendo con las de la opulencia o ingreso real, que identifica el elemento constitutivo como el acceso a bienes y servicios, el de los bienes primarios de Rawls, y los enfoques de las capabilities y los functionings ${ }^{1}$ de Sen y Nussbaum. La crítica al utilitarismo retoma, de manera muy esquemática, las críticas centrales de Sen y de Rawls (las de este último se sintetizan como las críticas de los gustos caros y de los gustos ofensivos, mientras que a la crítica de Sen la he llamado, para que complemente más claramente las de Rawls, crítica de los gustos baratos). Me parece que las tres críticas juntas son demoledoras. En cambio, la crítica de Sen al enfoque de los bienes primarios de Rawls y a lo que Sen

${ }^{1}$ Sobre el significado de capabilities y functionings y la razón de su no traducción, véase la nota 5 en el artículo de Julio Boltvinik en este número, p. 57. [Nota del editor.] 
llama el enfoque de la opulencia, como lo argumento en Crítica de la EPP, equivoca el adversario central al que tendría que derrotar para fundar su enfoque. Éste, me parece, es el enfoque que sostiene que el elemento constitutivo del eje del nivel de vida es la satisfacción objetiva de las necesidades humanas, el cual no existe para Sen.

La crítica al utilitarismo la he complementado con una crítica a la teoría neoclásica del consumidor (TNC), sostén central de la economía política dominante (pero que se presenta a sí misma como economics, como teoría científica pura). Esta crítica tiene dos vertientes. Por un lado retomo la crítica que hace Peter Penz (y que también hacen suya Doyal y Gough), y por otro presento una crítica propia, basada en el análisis de dos obras especializadas sobre el tema, que muestran que la TNC: 1) parte de un rechazo explícito de las necesidades pero se ve obligada a reintroducirlas subrepticiamente después, y 2) que esta teoría no resiste la introducción de necesidades en el esquema. Se muestra que los axiomas que sostienen esta teoría son inválidos tanto para los pobres como para la clase alta y que la TNC sólo funcionaría para seres sin necesidades, como los robots.

A continuación, Crítica de la EPP aborda los enfoques de las capabilities (EC) de Sen y de Nussbaum, que son muy diferentes entre sí. Respecto al EC de Sen, se sintetizan las críticas (con las que concuerdo) de Bernard Williams, Gerald Cohen, John Rawls, Frances Stewart, David Crocker, Des Gasper y (las críticas más bien implícitas) de Meghnad Desai y Sabina Alkire. De una manera general, estas críticas señalan, entre otras cosas, que el EC es una teoría vacía que requiere especificarse y fundamentarse; que el EC minimiza el lado pasivo del ser humano y sobreestima el papel de la libertad; que identifica como $\mathrm{ca}$ pabilities algo distinto a las capacidades humanas que se hacen posibles con la satisfacción de necesidades humanas; que en él sólo caben las capabilities que se derivan de la posesión de bienes; que las tasas de conversión de bienes a functionings (que es el elemento distintivo entre el EC y el enfoque de la opulencia) no son comparables entre personas que tienen conjuntos distintos de functionings; que las capabilities son inobservables; que al abstenerse de toda valoración, el EC es incapaz de ordenar conjuntos de consumo, ni de categorizar ninguna capability co-

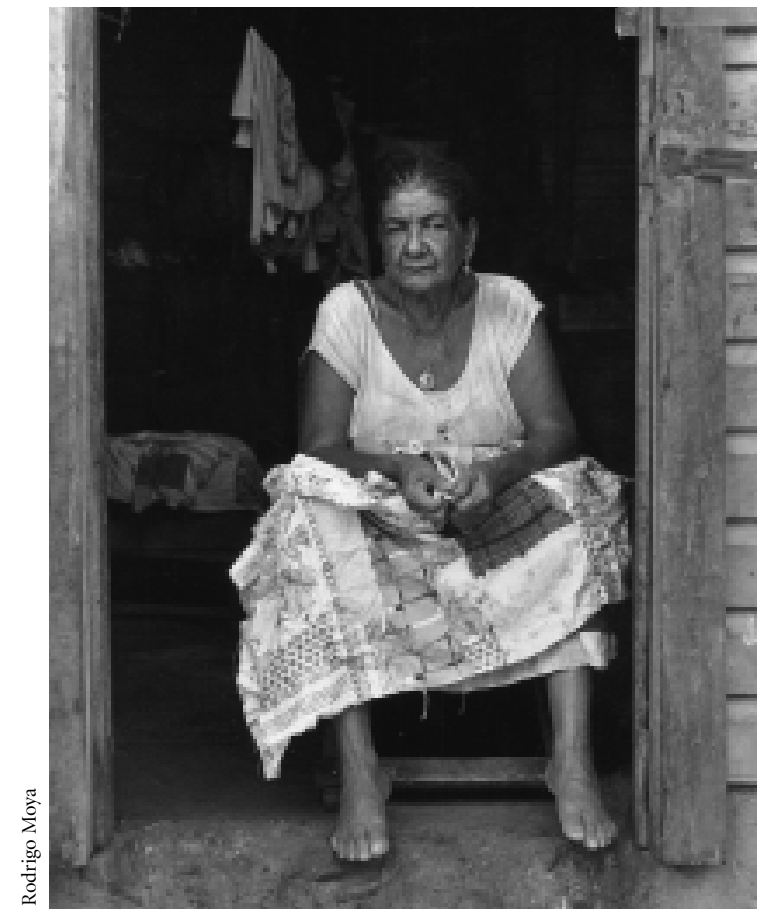

Panamá, Panamá, 1965.

mo no valiosa o identificar las perniciosas. De mi propia crítica derivo, entre otras, las siguientes conclusiones: que el EC de Sen es un enfoque mecanicista dado que los functionings dependen sólo del ingreso (o titularidades) y, por tanto, sólo del consumo de bienes y servicios; por ello, su universo se reduce a lo que se deriva del consumo de bienes y servicios y excluye satisfactores como relaciones y actividades; que al utilizar funciones subjetivas de evaluación, no observables, mantiene tres vicios del utilitarismo que se explican en Crítica de la EPP; que es una teoría de capacidades sin capacidades, en la cual la única capacidad es la de poseer mercancías y que (por omisión, al abstenerse de formular una ley de rendimientos decrecientes del ingreso en términos de functionings) tiende a avalar (paradójicamente, él que ha escrito tanto, $y$ tan bien, sobre el tema) la desigualdad.

Nussbaum, a pesar de seguir hablando de capabilities ha desarrollado un enfoque sustancialmente distinto al de Sen y mucho más cercano al enfoque de Ampliar la mirada. En Crítica de la EPP se destacan las diferencias que 
la propia autora identifica entre su enfoque y el de Sen y se presentan dos críticas: la no problematización de la vida en el capitalismo a través de conceptos como alienación, y su intento de reducir todos los rasgos de la buena vida a capabilities (lo que no funciona), cuando deberíamos, al menos, hablar de necesidades desarrolladas y satisfechas, capacidades desarrolladas y aplicadas, libertades negativas, derechos y oportunidades.

En las dos secciones finales de Crítica de la EPP abordo la crítica externa de un grupo de definiciones de pobreza, representativo de diversas tendencias dominantes dentro de la EPP, así como lo que he llamado el mapa conceptual de la EPP, su concepción de necesidades, satisfactores y recursos. Ambas secciones, en conjunto con las críticas al utilitarismo y al EC de Sen, conforman la crítica de la EPP. En la primera he identificado cuatro tipos de definiciones: 1) el enfoque convencional de necesidades de la pobreza (ejemplificada por Altimir, Boltvinik y, paradójicamente, por Sen y Foster), 2) lo que he llamado búsquedas fallidas de un nuevo enfoque (Townsend y Sen); 3) el enfoque economicista dominante (ejemplificado con CiAmpliar la mirada. Los tres primeros conforman la mayor parte del objeto de la crítica de la EPP. Al segundo grupo lo llamo así porque concluyo del análisis realizado que tanto Townsend como Sen intentan infructuosamente alejarse del concepto de necesidades y quedan atrapados en la EPP dominante. Respecto al enfoque economicista dominante concluyo que, como la utilidad es inobservable, los autores terminan en los hechos o sustituyéndola por la "satisfacción de expectativas" (Hagenaars) o por una definición tautológica en la cual la pobreza es la insuficiencia de ingresos para alcanzar un nivel referencial de ingresos" (Citro y Michael, y Ravallion).

En la última sección de Crítica de la EPP elaboro un cuadro a partir de las clasificaciones (tipologías) de necesidades, satisfactores y fuentes de bienestar (o recursos). La clasificación de necesidades adoptada se basa en la de Maslow sin las necesidades estéticas, que es la que en mi opinión podría generar un consenso parcial entre los autores examinados en Ampliar la mirada. Adopto una tipología de siete tipos de satisfactores elaborada a partir de la concepción antropológica de Marx, interpreta- da por György Márkus, de las tipologías de Lederer y de Kamenetsky retomadas por Doyal y Gough, y de la visión de satisfactores de Max Neef et al. Por último, la clasificación de recursos es la de fuentes de bienestar, que elaboré hace más de tres lustros como parte de mi crítica a los métodos de medición de la pobreza.

Con apoyo en el cuadro, los enfoques de la pobreza son entonces caracterizados según la amplitud o estrechez con la cual conciben las necesidades humanas, los satisfactores que posibilitan su satisfacción y los recursos (o fuentes de bienestar) que hacen posible el acceso a los satisfactores. Este análisis permite concluir que tanto los autores clasificados como enfoque convencional de necesidades como los clasificados en búsquedas fallidas de un nuevo enfoque son reduccionistas en las tres dimensiones: necesidades, satisfactores y recursos, y que este triple reduccionismo está estructuralmente vinculado: 1) omiten las necesidades emocionales y de crecimiento ( $\mathrm{y}$ con frecuencia las cognitivas); 2) omiten los satisfactores relaciones, actividades, conocimientos y teorías; capacidades e instituciones, asociados con las necesidades omitidas; y por último, 3) omiten los recursos 'tiempo' y 'conocimientos/habilidades', asociados con los satisfactores omitidos. Así, tanto el enfoque convencional de necesidades como el de búsquedas fallidas de un nuevo enfoque (éste una vez 'deconstruido') expresarían su objeto de estudio como: "sólo necesidades materiales que se satisfacen únicamente con objetos, para lo que se requiere exclusivamente ingresos corrientes". El enfoque economicista dominante que rechaza el concepto de necesidades se sitúa en un vacío conceptual que no puede llenar la utilidad, que es un concepto sin contenido.

El cuadro completo expresa la visión del eje de nivel de vida (ENV) del nuevo enfoque adoptado, es decir, como la perspectiva económica del eje de florecimiento humano. Por ello, el reduccionismo identificado en los enfoques convencionales muestra la enorme distancia que media entre la concepción del ENV en el nuevo enfoque y en el convencional, mostrando que el ENV derivado del EFH es muy diferente del que se configura cuando se le aborda directamente. El reduccionismo es, pues, una consecuencia inevitable del abordaje directo del ENV. Esta es la conclusión que he llamado la tesis crítica en Ampliar la mirada. 


\section{MIRADA UTOPISTA}

Ruth Levitas, en su artículo "Florecimiento humano: ¿una agenda utopista?" (en adelante Mirada utopista), sostiene que el "florecimiento humano es intrínsecamente una agenda utopista en tanto que se enfoca, más allá del presente, a un orden social transformado como condición necesaria de dicho florecimiento", lo que unificaría las agendas del florecimiento humano y de la utopía. Y aunque declara que es "imposible imaginar" el florecimiento humano porque "no podemos prever las necesidades, deseos y capacidades de los seres humanos del futuro", estamos obligados a intentarlo porque sólo esa visión nos da el "apoyo necesario para el cambio por la vía de la crítica de las condiciones actuales". Pone, por tanto, como requisito esencial del pensamiento al respecto el de separar "los registros de la existencia utópica y de la real".

En la primera sección, Mirada utopista explora las percepciones de diversas fuentes y estudios sobre la relación entre dinero o ingreso alto y felicidad. Analiza las evidencias que muestran que, a pesar de que el ingreso aumentó en el Reino Unido entre 1957 y 2006, la proporción de personas que han dicho ser muy felices ha decaído. Levitas advierte que cuando las expectativas de felicidad son más elevadas, la percepción de lo alcanzado puede ser más baja. Además, sostiene que cuando se hace un análisis más serio de las cifras disponibles sobre la relación entre PIB per capita y felicidad entre países (y entre ricos y pobres dentro de cada país), se encuentra una asociación positiva entre ambas variables con la excepción de los países latinoamericanos, que tienen altos niveles de satisfacción a pesar de sus bajos PIB per capita, lo que se explicaría por una disposición cultural hacia la vida, según los autores a quienes cita con aparente aprobación. Los aumentos en la riqueza agregada a lo largo del tiempo no son acompañados por aumentos en la felicidad. La autora considera que estas mediciones son banales y que constituyen un enfoque simplista e inadecuado del florecimiento humano.

En la siguiente sección de Mirada utopista ("El problema del crecimiento económico"), Levitas aborda las críticas de los indicadores del crecimiento económico como indicadores del bienestar y reseña algunas de las medidas alternativas que se han desarrollado. Con algunos indicadores que siguen siendo económicos, dice Levitas, ya que parten del PIB y lo ajustan deduciendo costos ambientales y de criminalidad, le suman el valor del trabajo doméstico y ajustan por desigualdad, la evolución del bienestar (en los países desarrollados con los que ejemplifica) es totalmente distinta que con el PIB: la imagen de progreso se desvanece. Pasa revista también a indicadores sobre la calidad de la vida, entre ellos el Índice de Desarrollo Humano del Programa de las Naciones Unidas para el Desarrollo. Todos estos son indicadores agregados casi siempre a nivel nacional. A nivel de las personas y con una idea más amplia de bienestar, Levitas analiza un estudio piloto con niños y jóvenes, que profundiza en indicadores subjetivos de bienestar.

La última y más larga sección de Mirada utopista, "Imaginar el florecimiento humano", comienza analizando, desde la perspectiva de los estudios utópicos, el manifiesto de la New Economics Foundation (de la cual ha referido antes trabajos, incluyendo el mencionado estudio piloto) titulado A Well-being Manifesto for a Flourishing Society (de aquí en adelante el Manifiesto). Concluye que el Manifiesto es en algunos aspectos utópico en el mejor sentido de la expresión, en otros es utópico en el sentido despectivo, y en otros más ni siquiera alcanza a ser utópico, argumentando ampliamente cada una de estas caracterizaciones.

Pasa entonces la autora a temas conceptuales de fondo. En primer lugar, asociando el problema de la capability en el Manifiesto y en Sen, critica la concepción de éste señalando que "las capabilities a desarrollar son siempre aquellas que se valoran en el mercado" y que "la noción de un ser humano capaz se ve acotada, en el contexto de la economía neoliberal, a un actor económico capaz" y añade que "las capabilities como las concibe Sen son en esencia económicas y muy distantes de cómo concibe Marx las capacidades", críticas con las que concuerdo. El manifiesto se apoya en las teorías de las necesidades de Maslow y Max Neef et al. con las cuales Levitas está en desacuerdo. A partir de aquí aparecen diferencias importantes entre la concepción de Levitas y la mía, que pueden dar lugar a un esclarecedor debate que ya se ha iniciado por vía de la Internet y que aquí desplegaré y ahondaré 


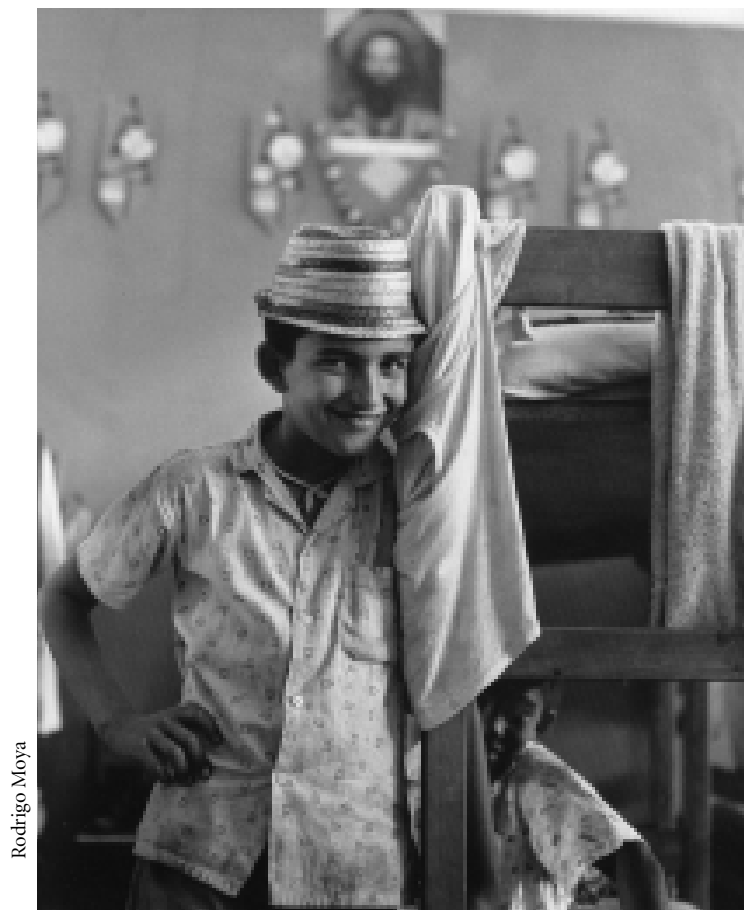

Santiago, Cuba, 1964.

(aunque ya no podré incorporar las nuevas respuestas de Levitas). El primer contrapunto de Levitas es en relación con la postura del Manifiesto que sostiene que una vez que las necesidades básicas están satisfechas la ganancia material tiene poco impacto sobre el bienestar. Esta idea central para el igualitarismo (la igualdad es buena porque una unidad monetaria transferida de un rico a un pobre se traduce en mayor bienestar social y porque daría una base racional adicional para poner alto a la espiral producción/consumo que tanto preocupa a Leiss y a Levitas) es rechazada por Levitas de la siguiente manera:

El problema esencial es que las necesidades, las apetencias (wants) y las satisfacciones, y las incompatibilidades entre ellas, son generadas socialmente [...] Leiss pone en duda la posibilidad de distinguir entre necesidades y apetencias, $o$ entre necesidades 'reales' $y$ 'falsas'. Esto es porque (como Max Neef también acepta ${ }^{2}$ ) mientras la distinción entre necesida-

${ }^{2}$ La autora no da la referencia para cotejar esta aceptación de Max Neef que yo no he encontrado. des básicas y superiores puede ser defendible a cierto nivel de abstracción, en la práctica las necesidades y los satisfactores funcionan como una formación histórica concreta, en la cual los medios para enfrentar las necesidades tienen en sí mismos un significado social. La distinción entre necesidades básicas y superiores se desvanece entonces en la práctica.

Note el lector cómo Levitas, en esta cita, pasa de una distinción a otra (he resaltado las distinciones con cursivas): empieza con necesidades y apetencias, pasa a necesidades básicas y superiores, continúa con necesidades y satisfactores y termina con necesidades básicas y superiores. Pero antes de polemizar con Levitas, continuemos con su exposición. La autora sostiene que las bibliografías sobre felicidad y bienestar, lo mismo que aquellas sobre pobreza, desarrollo y capabilities, casi no entran al registro utópico. Vuelve entonces a la idea que da título a su artículo: "la idea misma de florecimiento humano es una idea utópica", pero el "intento de imaginar la utopía, la sociedad en donde el florecimiento humano se torna posible, es necesariamente un fracaso. El proyecto de movilizar un concepto utópico dentro de los confines de una sociedad lejana de la utopía y marcada por la pobreza y la desigualdad, siempre enfrenta este problema”. Y añade que este problema está presente también en mi enfoque.

Levitas argumenta en contra de mi crítica a Townsend por reducir, como otros autores, "la pobreza y la riqueza humanas al eje económico" a "pesar de la visión mucho más amplia de pobreza de la que parte este autor". Levitas limita su argumento a citar la definición de pobreza de Townsend y a confirmar que efectivamente este autor sostuvo que era posible definir empíricamente un nivel de ingreso por debajo del cual la exclusión [de los patrones ordinarios de vida, costumbres y actividades] es inevitable ${ }^{3}$. El lector de este número de Desacatos tendrá acceso

\footnotetext{
${ }^{3}$ Ruth Levitas tenía que salir en defensa del enfoque de Townsend porque ella es parte destacada de lo que se podría llamar la Escuela de Townsend o la Escuela de Bristol del estudio de la pobreza, formada por un grupo muy relevante de investigadores que trabajan bajo el liderazgo intelectual y moral de Townsend, en el Townsend Center for International Poverty Research de la Universidad de Bristol. La obra más reciente de este grupo de investigación sobre pobreza es Christina Pantazis, David Gordon y Ruth Levitas (eds.), Poverty and Social Exclusion in Britain: The Millenium Survey, Policy Press, Reino Unido, 2006, 488 pp., en el cual Townsend es coautor de dos importantes capítulos.
} 
a la argumentación completa (en la sección 6 de Crítica de la EPP) que me lleva a sostener que Townsend estrechó su mirada ${ }^{4}$ a pesar de su amplia definición. Townsend ha sido muy ambiguo en cuanto a la amplitud de su mirada, pues por una parte ha mantenido una visión del universo de satisfactores, necesidades y recursos mucho más amplia que la predominante (en Poverty in the United Kingdom utilizó 60 indicadores de privación). Pero por otra parte, ha incurrido en un fuerte reduccionismo al recomendar el uso de líneas de pobreza absolutamente relativistas y en el capítulo 6 de Poverty in the United Kingdom, al reducir la amplia gama de recursos (ahí mismo concebida) al ingreso en su búsqueda de la línea de pobreza objetiva. En ambos casos, los medios se reducen al ingreso y los satisfactores a aquellos que se pueden adquirir con dinero. Lo anterior lleva inevitablemente a reducir también los fines (necesidades por satisfacer). Sin embargo, Levitas está de acuerdo en que la pobreza se asocia generalmente sólo con la carencia de "recursos materiales" y sostiene que en los estudios de exclusión social se han incluido "cuestiones sociales a la agenda de pobreza”. Con ello, aunque se amplía un poco la mirada, no se logra revertir el reduccionismo anotado ${ }^{5}$.

Levitas critica correctamente una frase de mi síntesis del enfoque de Ampliar la mirada ("El objetivo último de las políticas públicas debe ser el pleno florecimiento humano") al señalar que al no hacer la distinción explícita entre utopía y políticas públicas para el aquí y el ahora, caigo en el mismo error que el Manifiesto. Se trata de un error sin consecuencias para el conjunto de mi enfoque que ya he corregido: en Crítica de la EPP he añadido a la frase criticada el matiz de "en un Estado ideal, probablemente utópico".

\footnotetext{
${ }^{4} \mathrm{La}$ Babel en la que me coloco al seguir escribiendo en español me obligó a que el diálogo con Levitas se estableciese a partir de dos materiales muy sintéticos de mi enfoque: una presentación en Power Point en inglés, misma que presenté en un seminario en mayo de 2005 en la Universidad de Bristol, y un resumen en inglés (casi idéntico a la sección 2 de Crítica de la EPP) que le envié.

${ }^{5}$ La obra citada en la nota 2, de la que es coautora Levitas, contiene algunos avances interesantes en el desarrollo de indicadores de exclusión social. Sin embargo, son obvios dos problemas adicionales al anotado en el texto: 1) el desarrollo de un concepto paralelo al de pobreza fragmenta la visión en vez de integrarla; 2) las relaciones y diferencias entre ambos conceptos son muy borrosas.
}

\section{UN DEBATE CON MIRADA UTOPISTA}

El meollo de la crítica de Levitas a mi enfoque se refiere a tres distinciones que yo asumo y que a ella le parecen problemáticas: la distinción entre necesidades bajas y superiores (tomada de Maslow), la distinción entre necesidades y apetencias (wants) y la distinción entre necesidades y satisfactores. Mi argumento de que la segunda distinción es demostrable por el daño humano que se ocasiona cuando las necesidades, en oposición a las apetencias, no son satisfechas recibió la siguiente réplica de Levitas: "Sin embargo, si el daño se entiende como obstáculo al florecimiento humano [lo cual yo no afirmo, aunque sería una posible forma de definirlo], la distinción deviene otra vez problemática. Empero, el hecho de que las necesidades básicas no estén satisfechas para la mayoría de la población en el mundo necesariamente inhibe el florecimiento humano: superar la pobreza económica es condición necesaria pero de ninguna manera suficiente para el florecimiento humano". El asunto de las distinciones lo discuto infra. La frase que he marcado en cursivas queda vaga al no explicar la autora en qué sentido la distinción deviene otra vez problemática. A la crítica a la distinción de necesidades y apetencias se puede replicar, en un primer momento, de la siguiente manera: si en la frase citada de la autora reemplazamos necesidades por apetencias observaremos que pierde sentido: "el hecho de que las apetencias básicas no estén satisfechas para la mayoría de la población en el mundo necesariamente inhibe el florecimiento humano". Además, el daño no sólo se puede entender como obstáculo al florecimiento humano, sino desde diversas perspectivas, pero la pérdida de la salud física y mental es la más obvia y contundente, y es a la que se refieren Fromm, Maccoby, Maslow y Doyal-Gough.

La tesis de Levitas, apoyada en William Leiss como vimos, tiene su momento más fuerte en la frase: "en la práctica las necesidades y los satisfactores funcionan como una formación histórica concreta, en la cual los medios para enfrentar las necesidades tienen en sí mismos un significado social". El argumento tiene dos aspectos. Primero, la afirmación de que las "necesidades, las apetencias y las satisfacciones, y las incompatibilidades entre ellas, son generadas socialmente". Esto está relacionado con 
una idea sugerida, pero no desarrollada, por Max Neef $e t$ al. sobre las relaciones entre necesidades, satisfactores y bienes $^{6}$. Esta línea de razonamiento tiene como premisa la utilidad de la distinción analítica entre necesidades y satisfactores; de otra manera las dos frases de Levitas citadas en este párrafo carecerían de sentido. Una vez aceptada esta distinción el problema pasaría a ser el de analizar las relaciones entre ellos, como querían Max Neef et al. Una cosa es decir que los medios de satisfacer necesidades tienen un significado social y otra muy diferente que las necesidades y los satisfactores están completamente embrollados y no pueden distinguirse del todo (que no es posible distinguir el hambre de los alimentos). Un Cadillac es un satisfactor de la necesidad de transporte, pero "estar privado de poseer un Cadillac" es una frase sin sentido, mientras estar privado de transporte puede resultar mortal. Satisfactores de la misma necesidad son sustituibles entre sí (si uno no tiene un Cadillac puede usar un auto pequeño, el transporte público o una bicicleta), pero las necesidades no son sustituibles unas por otras. $\mathrm{Si}$ uno está enfermo y no puede llegar a la clínica puede resultar seriamente dañado. Ciertamente, los medios de satisfacción son significativos en sí mismos pues se vuelven, como Veblen, Bourdieu y Baudrillard, entre otros, han mostrado, signos de distinción social y, por tanto, de pertenencia a cierta clase. Pero siguen siendo medios y pueden ser sustituidos unos con otros. En el texto de Levitas, la distinción entre necesidades y satisfactores se ha embrollado con la distinción entre necesidades bajas $y$ superiores: inmediatamente después de sostener que en la práctica "las necesidades y los satisfactores operan como una formación histórica concreta”, la autora concluye: "La distinción entre necesidades básicas y superiores se desvanece entonces en la práctica”. Pero son dos dis-

\footnotetext{
${ }^{6}$ A manera de ejemplo, véase lo que dicen Dicen Max Neef et al.: "Cuando la forma de producción y consumo de bienes conduce a erigir los bienes en fines en sí mismos, entonces la presunta satisfacción de una necesidad empaña las potencialidades de vivirla en toda su amplitud [...] la vida se pone, entonces, al servicio de los artefactos en vez de los artefactos al servicio de la vida. La pregunta por la calidad de la vida queda recubierta por la obsesión de incrementar la productividad de los medios" (en Desarrollo a escala humana. Una opción para el futuro, núm. especial de Development Dialogue, Uppsala, Suecia, y Santiago de Chile, 1986).
}

tinciones diferentes y que deben mantenerse separadas. Sen reconoce la primera pero no la segunda distinción, mientras Maslow, autor de la segunda, no menciona la primera. La distinción entre necesidades y apetencias es esencial para imaginar o diseñar una sociedad futura.

Estos argumentos se los envié a Levitas, quien respondió señalando que:

si bien el Cadillac es un buen ejemplo, uno más actual en el Reino Unido [y habría que añadir también en México] son las camionetas $4 \mathrm{x} 4$, monstruos contaminantes devoradores de gasolina, que la gente cree que necesita porque tiene que transportar muchas cosas y a los niños y si uno tiene un accidente con ellos las probabilidades de que los niños se maten son menores (en el accidente, aunque puedan morir de asma por las emisiones del tráfico). El argumento es que en la práctica un vehículo nunca es 'sólo' un medio de transporte, sino que ocupa una posición mucho más compleja en la matriz de necesidades (transporte, seguridad, estatus) $y$ satisfacciones. El hilo central de mi argumentación se refiere a la distinción entre necesidades básicas/bajas y necesidades superiores, no a la separación analítica entre necesidades y satisfactores, de la cual admito haber pasado sobre ella sin mucho comentario. Hay aquí un desacuerdo sustantivo entre ambos sobre la relación entre necesidades y satisfactores. La implicación del argumento de Leiss —en el cual la distinción entre necesidades y apetencias es problematizado- es que en el nivel concreto las necesidades/ apetencias son generadas en una relación dialéctica con los satisfactores. No considero estar confundida sino sólo en desacuerdo contigo.

Respecto a mi afirmación sobre el papel central de la distinción entre necesidades y apetencias para imaginar o diseñar una sociedad futura, Levitas contestó:

Aquí discrepo del tono inequívoco de la afirmación. Estoy de acuerdo y en desacuerdo. Es poco marxista por las razones establecidas en el primer y segundo párrafos del artículo ${ }^{7}$.

\footnotetext{
${ }^{7}$ De los contenidos de los dos primeros párrafos me parece que dos son las ideas clave a las que (posiblemente) alude la autora: "Como Marx y los marxistas siempre lo entendieron, es imposible imaginarlo, porque no podemos prever ni cerrar anticipadamente (foreclose) las necesidades, deseos y capacidades de los seres humanos del futuro; no sabemos lo que ellos o nosotros podamos ser entonces". La segunda sería: "El intento de conceptualizar la utopía o el florecimiento humano en el presente, siempre y necesariamente conduce a estrechar y distorsionar estos conceptos, incluso cuando apuntan a algo que
} 
Para visualizar una sociedad diferente, uno tiene que imaginar la posibilidad de que las personas necesiten/apetezcan de otra manera y creer que ello es deseable. Pero uno tiene que entender también que esto involucra una reestructuración de todo el complejo de necesitar/apetecer.

Antes de comentar la respuesta de Levitas quiero hacer una aclaración. Ahora me percato que además de embrollar las distinciones entre necesidades/satisfactores y necesidades bajas/superiores, Levitas parece igualar esta última distinción con la de necesidades/apetencias. Como dije antes, son tres las distinciones en disputa: 1) necesidades y satisfactores, que es una distinción entre medios $y$ fines, pero también entre sujeto necesitante y objeto $s a$ tisfactor; 2) necesidades y apetencias, que es una distinción entre dos nociones cercanas que se pueden distinguir, al menos, de dos maneras: por su grado de cercanía a los extremos de lo indispensable o lo superfluo, o por el efecto que su insatisfacción produce: desde grave daño hasta una pequeña frustración; 3) necesidades bajas y superiores, que es una distinción exclusiva de la teoría de la jerarquía de necesidades de Maslow ${ }^{8}$. Levitas fusiona las

está más allá de ellos mismos. Resulta por ello esencial la separación de los registros de la existencia utópica y de la real, a fin de que los límites actuales de las ideas sobre el bienestar, y la necesidad de un cambio estructural radical como la condición del bienestar, sean enfocados más claramente". Ya declaré mi acuerdo con la segunda idea y estoy también de acuerdo con la primera. Pero el punto en discusión es de carácter metodológico y no sustantivo: si para delinear una sociedad futura requerimos o no distinguir necesidades de apetencias. Sin embargo, la idea de la "reestructuración de todo el complejo de necesitar/apetecer" podría entenderse como que todas nuestras categorías al respecto fueran invalidadas.

${ }^{8}$ Es probable que la afirmación del texto sea, en rigor, falsa (aunque sea correcta en el contexto de la discusión con Levitas y Leiss), ya que J. P. Terrail ("Necesidades, consumo y ocultamiento de las relaciones de producción”, en J. P. Terrail et al., Necesidades y consumo en la sociedad capitalista actual, Grijalbo, México, 1977, p. 267), señala lo siguiente refiriéndose a una obra de M. Halbwachs de 1912: "el estudio sucesivo de los efectos del nivel de ingresos y del tamaño de la familia sobre la organización del presupuesto familiar muestra la coherencia de los comportamientos de consumo obreros; su regularidad obliga a considerar la realidad social concreta de una escala de valores y de una jerarquía de las necesidades". La famosa Ley de Ángel, seguramente comprobada por Halbwachs sobre la proporción descendente del gasto en alimentos en el gasto total del hogar a medida que subimos en la escala de ingresos, está en el mismo registro. Esta ley se ha comprobado empíricamente en casi todo el mundo y en diferentes momentos del tiempo. Hay una jerarquía de necesidades que se expresa en la asignación de los presupuestos familiares. Además, hay otras evi- últimas dos distinciones, lo que puede explicarse porque describe la teoría de Maslow como si éste usase el par conceptual necesidades básicas/superiores en lugar de bajas/superiores (véase mi aclaración en la nota 10 del artículo de Levitas). Como las necesidades básicas se suelen oponer a las no básicas, la cercanía entre éstas y las apetencias lleva al resultado mencionado, ya que se traslada la distinción de Maslow del eje deficitario/crecimiento al eje indispensable/superfluo que, como hemos visto, es el que corresponde a la distinción necesidades/apetencias ${ }^{9}$. Al hacerlo así, la necesidad de autorrealización de Maslow, que expresa de otra manera el florecimiento humano, queda en calidad de apetencia. Levitas rechaza la validez de las dos primeras distinciones y utiliza la tercera como sinónimo de la segunda.

Volviendo a la respuesta de la autora de Mirada utopista he marcado en ella con cursivas cuatro frases importantes. Cuando Ruth Levitas dice que la gente cree que necesita, refiriéndose a las camionetas $4 \times 4$, está implicando que hay algo objetivo en las necesidades que no necesariamente coincide con lo que la gente cree o percibe, con lo que quiere, con sus apetencias y, por tanto, se está contradiciendo y avalando implícitamente la distinción necesidades/apetencias. La segunda frase marcada en cursivas refleja en mi opinión una percepción certera, los bienes se ubican en la matriz completa de necesidades y pueden desempeñar varias funciones. La tercera frase es muy importante, es la frase que intenta responder a mi crítica sustantiva cuando sostengo que ambas distinciones (ahora sabemos que son tres) deben mantenerse separadas. En efecto, en la frase la autora logra poner juntos los términos necesidades/apetencias por un lado, y satisfactores por el otro. Al parecer el argumento de Levitas (siguiendo a Leiss) es el siguiente: si necesidades/apetencias no es una distinción válida y si 'ambas' son generadas en una relación dialéctica con los satisfactores, podría entonces sos-

\footnotetext{
dencias a favor de la jerarquía de necesidades. Véase al respecto el inciso 3.8.3 de Ampliar la mirada.

${ }^{9}$ Esta conjetura la he comprobado al leer el escrito de la autora citado en la siguiente nota, en cuyas páginas 21-22 se encuentra este texto: "Los problemas de definir la pobreza involucran las mismas distinciones [que el pensamiento utopista] entre 'necesidades' y 'apetencias', o 'necesidades básicas' y otras necesidades".
} 


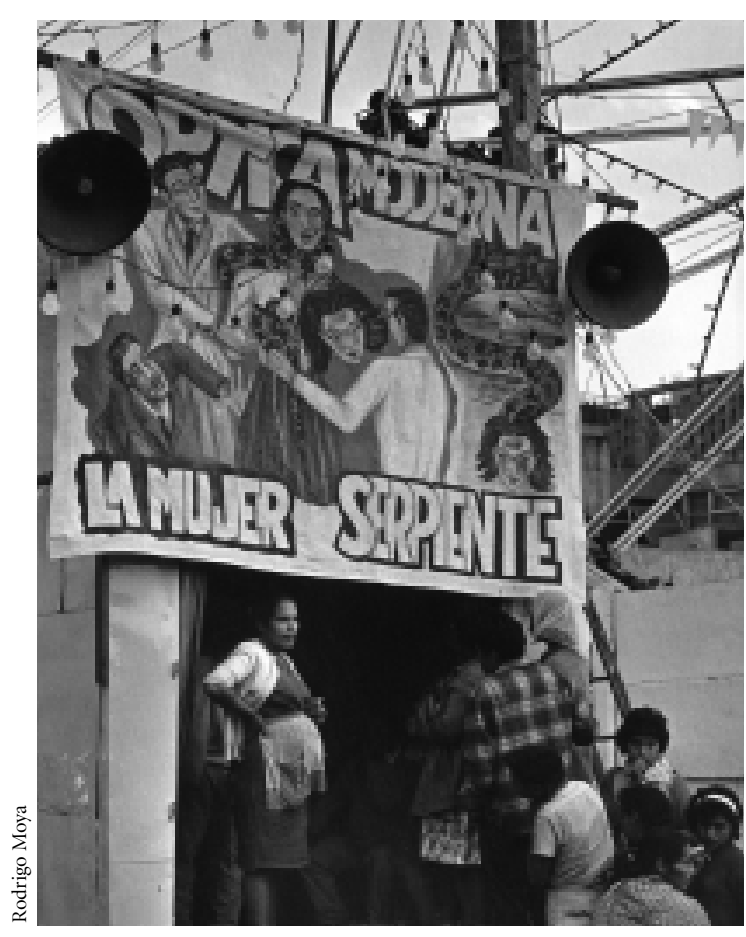

Tacuba, ciudad de México, ca. 1960.

tenerse que la distinción entre los tres términos deja de existir. Esto podría interpretarse irónicamente como que la apetencia por la crema para el cuello está tan incorporada en la crema que la distinción entre objeto y sujeto deja de existir, que la crema es la portadora de los impulsos. Pero resulta obvio que no puede haber "relación dialéctica" entre dos entes que no pueden distinguirse uno del otro. Marx no desaparece el valor o el valor de uso cuando establece entre ellos ( $\mathrm{y}$ con su forma de manifestarse el primero, el valor de cambio) una intensísima relación dialéctica.

Para continuar nuestro diálogo, Ruth Levitas me envió un trabajo suyo ("Need, Nature and Nowhere"10, en adelante Necesidad y naturaleza), en el cual expone con mayor detalle los argumentos de William Leiss en The Limits to Satisfaction ${ }^{11}$. Los siguientes extractos intentan

${ }^{10}$ Ruth Levitas, "Need, Nature and Nowhere", en Peter Alexander y Roger Gill, Utopias, Gerald Duckworth, Londres, 1984, pp. 19-30.

${ }^{11}$ Para fines de esta presentación decidí que lo importante es la lectura sintetizar al máximo posible su exposición sin que sus argumentos pierdan fuerza. Para no interrumpirla, mis comentarios están expresados en (a veces muy largos) pies de página. Para distinguir mis énfasis de los de la autora, las cursivas son mías, mientras los subrayados son cursivas en el original.

Si tales necesidades [las básicas] pudiesen ser distinguidas, tendría sentido argumentar que la separación del pensamiento utópico respecto de la política práctica y de la ingeniería social estimularía la exploración de aquellas necesidades y de los medios de satisfacción. Sin embargo, no estoy argumentando solamente que la experiencia de privación o que la percepción de las necesidades básicas son socialmente relativas; estoy más bien sosteniendo que no es posible definir un conjunto de necesidades humanas básicas a la satisfacción de las cuales, entonces, la utopía pueda diseñarse. El problema de distinguir necesidades básicas de otras, o necesidades de apetencias, ha sido mejor expuesto por Leiss (197812); esbozaré su argumento y pasaré a desarrollar sus implicaciones para el pensamiento utopista.

Leiss no niega que haya ciertas necesidades objetivas que pueden ser identificadas, tales como la necesidad de un mínimo de ingesta nutricional, condiciones apropiadas para retener o disipar calor corporal, y experiencias de socialización para mantener la cohesión de los animales sociales como el hombre (p. 72). Pero no sólo son estas necesidades comunes a muchas especies y, por tanto, difícilmente definidoras de las necesidades humanas básicas ${ }^{13}$, sino que están expresadas a un nivel de abstracción que oscurece el problema. Expresadas de esta manera, podrían ser vistas como 'naturales', como las condiciones objetivas requeridas para la sobrevivencia del organismo. Sin embargo, la disputa sobre las necesidades 'básicas' nunca ocurre a este nivel: el problema surge cuando éstas son trasladadas a necesidades de tipos particulares de alimentos, en cantidades específicas, con calidades específicas, y lo mismo para ropa [... etc.].

que Levitas hace de Leiss y no tanto las ideas de éste. Por tanto, restrinjo la discusión que sigue a esta lectura. La descripción detallada de las ideas de Leiss y la discusión con él puede verlas el lector en la serie de entregas semanales de "Economía Moral" en La Jornada iniciada el 5 de enero de 2007 con el título de "Los límites de la satisfacción”.

${ }^{12}$ La autora cita una edición del libro de Leiss distinto al que yo cito. La de ella es de 1978 y fue publicada por Marion Boyars, Londres.

${ }^{13}$ Las necesidades humanas constituyen un conjunto conformado por necesidades que compartimos con otras especies (aunque en nuestro caso las hemos humanizado, convirtiendo, por ejemplo, la necesidad sexual en erotismo) y necesidades exclusivamente humanas. Por tanto, las primeras son también necesidades humanas. 
Los seres humanos nunca experimentan sus propias necesidades o las del prójimo al primer nivel de abstracción ${ }^{14}$. Éstas siempre son confrontadas en formas socialmente mediadas que especifican las necesidades para ciertos objetos concretos o procesos. Y porque las maneras socialmente prescritas de enfrentar las necesidades materiales ${ }^{15}$ también tienen significados simbólicos, uno no puede distinguir algunas necesidades, a este nivel menos abstracto, como más naturales o básicas ${ }^{16}$. Así:

No hay ningún aspecto de nuestros requerimientos fisiológicos (las famosas necesidades de alimentos, refugio y así sucesivamente) que no hayan estado siempre inmersas en una rica tapicería de mediaciones simbóli$\operatorname{cas}^{17}$. De igual manera, lo que se llama las necesidades superiores - amor, estima, la búsqueda del conocimiento y la perfección espiritual-surgen también en el marco de una interpretación holística de necesidades ${ }^{18}$ y no

${ }^{14} \mathrm{Si}$ así fuese no existiría la palabra necesidad en ningún idioma, ni las palabras para necesidades específicas, ni los términos para las situaciones carenciales genéricas (privación, carencia, pobreza); la frase "tengo hambre" carecería de sentido. Leiss basa todo su elaborado discurso en las clases altas de los países desarrollados ("La conducta de la minoría opulenta en las naciones desarrolladas es vista en este ensayo como un 'tipo ideal' del estilo de vida de alto consumo"; William Leiss, The Limits to Satisfaction. An Essay on the Problem of Needs and Commodities, McGill-Queen's University Press, Kingston y Montreal, 1988 [1976], p. 100) y por ello no quiere saber lo que es la visión del hambriento que Marx ha descrito con crudeza en la siguiente frase de los Manuscritos de economía y filosofia (Alianza Editorial, Madrid, 1999 [1844]: 146): "El sentido que es presa de la grosera necesidad práctica tiene sólo un sentido limitado. Para el hombre que muere de hambre no existe la forma humana de la comida, sino únicamente su abstracta existencia de comida: ésta bien podría presentarse en su forma más grosera, y sería imposible decir entonces en qué se distingue esta actividad para alimentarse de la actividad animal para alimentarse."

${ }^{15}$ Hay aquí un recorte inexplicable por el cual se excluyen las 'necesidades no materiales'.

${ }^{16}$ Es obvio que hay aquí un non-sequitur: el significado simbólico no elimina la naturaleza básica o no básica de una necesidad, es un asunto que está en otra dimensión. Para argumentar como lo hacen Leiss y Levitas, se tendría que sostener: 1) que lo simbólico es la única característica de las necesidades; y 2) que en la dimensión simbólica todo es igualmente importante.

${ }^{17}$ El argumento de la nota 13 apunta en la dirección de que las mediaciones simbólicas desaparecen en la presencia aguda de hambre, frío, etc. Al respecto, Los olvidados de Luis Buñuel, La peste de Camus, y las películas de Akira Kurosawa (Sueños y Dersu Uzala, por ejemplo) son "evidencias" concurrentes con la cita de Marx.

${ }^{18} \mathrm{Si}$ aceptamos, con David Wiggins (Needs, Values, Truth. Essays in the Philosophy of Value, Clarendon Press, Oxford, Gran Bretaña, 3a ed., 2002 [1987]), que necesitar no es un verbo intencional, también tendremos que suponer que no es necesariamente consciente. En este contexto, afirmar que las necesidades superiores surgen en el marco de una interpretación holística de las necesidades está totalmente fuera están separadas de los aspectos materiales de la existencia (Leiss, 1978, 75).

En otras palabras, la distinción entre naturaleza y cultura es inapropiada, puesto que no podemos experimentar la naturaleza excepto de una manera mediada por la cultura, y la interpretación de diferentes tipos de necesidades en un único sistema también nos impide construir órdenes jerárquicos de necesidades ${ }^{19}$.

de lugar: las necesidades no son el resultado de actividades intelectuales como la interpretación, sino que tienen un origen más profundo. Sin embargo, no es esta la opinión de Leiss, quien ha dicho que en todas las sociedades, "los hombres y las mujeres interpretan colectivamente, reflexionan sobre, e integran aquellos impulsos que de otra manera serían espontáneos y que normalmente llamamos la lucha por la preservación de la especie. Los impulsos son mediados y transformados por las formas culturales en necesidades, esto es, expresiones conscientes de deseos que quedan congelados en los patrones de socialización transmitidos de generación en generación" (Leiss, op. cit., p. 51). Con esta concepción de necesidades no es extraño que no las distinga de apetencias o deseos.

${ }^{19}$ Aunque la expresión mediaciones simbólicas no es muy clara (por lo menos para mí), puede interpretarse como un concepto paralelo en algunos sentidos al de humanización de las necesidades biológicas desarrollado por Marx, elaborado por Márkus y que yo he adoptado desde hace muchos años. En esta concepción, sin embargo, se distinguen las necesidades biológicas humanizadas de las necesidades humanas sin raíz biológica, como las necesidades estéticas, las religiosas y, al menos en mi opinión, las necesidades de estima y de autorrealización. Me parece que la afirmación de que la distinción entre naturaleza y cultura es inapropiada es insostenible. Note el lector en el texto de Levitas que, antes de la cita de Leiss, iguala necesidades más naturales a necesidades más básicas, por lo cual el rechazo a la distinción natural/cultural está orientado a rechazar la distinción entre necesidades básicas y no básicas (y, por tanto, como hemos visto, entre necesidades y apetencias). Parece conveniente dar un rodeo para aclarar el concepto de distinción al contrastarlo con el de dicotomía. Hilary Putnam (The Collapse of the Fact Value Dichotomy and Other Essays, Harvard University Press, Cambridge, Massachussets, 2002) en su ataque a la dicotomía hechos/valores ha considerado necesario "explicar las diferencias entre una distinción ordinaria y una dicotomía metafísica" (p. 60): "Cuando la distinción se vuelve una dicotomía — quizás debería haber usado el término de John Dewey, dualismo - típicamente se hace acompañar por un conjunto altamente contencioso de aseveraciones metafísicas" (p. 61). Algunas de las afirmaciones de Leiss y Levitas quizás harían sentido si se refirieran a dicotomías o dualidades, pero en mi opinión no lo tienen al estar formuladas en términos de distinciones. Una de las características de las dicotomías (cuyos términos se conciben como agudamente distintos y casi siempre como opuestos) es que no toleran la existencia de términos que compartan rasgos de ambos opuestos o que no se puedan clasificar en ellos. Esto es lo que ilustra Putnam en el capítulo 1 de su libro con la dicotomía entre juicios sintéticos (o falsificables) y analíticos (verdaderos o falsos de acuerdo con la lógica). Todo lo que no cabe en alguna de estas categorías es enviado por los positivistas lógicos a una tercera categoría, la de los juicios cognitivamente insignificantes. Putnam observa que una de las diferencias entre una distinción ordinaria y una dicoto- 
Aún más, Leiss argumenta que los complejos sistemas de necesidades se desarrollan en interacción con los medios para su satisfacción. Esto no se contradice por el hecho de que los utopistas frecuentemente incluyan medios para la satisfacción de necesidades que no existen [...]. [Leiss, 1978: 77] argumenta que la tendencia general de la economía de mercado de hoy $[\ldots]$ es [...] orientar las necesidades enteramente hacia mercancías'. La proliferación de mercancías para la satisfacción de las necesidades produce su refinamiento o fragmentación [...] La especialización crea un problema $[\ldots]$ pero no es $[\ldots]$ un problema de la creación de falsas necesidades [...] Más bien, resulta un estado de confusión por la dificultad de 'determinar la adecuación de los objetos producidos para los requerimientos de las necesidades' (Leiss, 1978: 95). Para identificar el producto precisamente correcto para satisfacer una necesidad específica se requiere una cantidad inmensa de conocimientos, tiempo y energía ${ }^{20}$.

mía metafísica es que las primeras tienen rangos de aplicación y uno no se sorprende si descubre que no siempre son aplicables. Sostiene que es válido distinguir entre hechos y valores pero es inválido postularlos como una dicotomía. Aplicando esta lección al campo que nos ocupa, podemos afirmar que los autores que respaldamos la validez de las diferencias entre necesidades y apetencias (o como quiere Levitas, básicas y no básicas), y entre necesidades y satisfactores, las concebimos como distinciones simples y no como dicotomías. Uno de los argumentos de Leiss para intentar demoler la distinción necesidades/apetencias es atacar el extremo más obvio de los requerimiento fisiológicos de alimentos, refugio, etc. Para ello pone el ejemplo de la novela anti-utópica We en la cual el único alimento es un derivado del petróleo y la vivienda es un pequeño cubículo con paredes de vidrio igualmente amueblado para todos. "Las 'necesidades' de todos son de esta manera satisfechas, dice Leiss, y el condicionamiento a lo largo de toda la vida asegura que no surjan apetencias que puedan trascender la esfera de las necesidades" (Leiss, op. cit., p. 62). Si éste fuese un método válido podríamos aplicarlo para demoler la distinción pobres/no pobres utilizando como caricatura (tristemente real) la línea de pobreza del Banco Mundial que, en el mejor de los casos, permite la adquisición de una dieta casi tan monótona (aunque quizás no tan repulsiva) como la de We, pero no permite satisfacer ninguna otra necesidad. La reducción al absurdo es en ambos casos la misma. Lo que sin duda logra la línea de pobreza del Banco Mundial es desacreditar el concepto de pobreza, como We logra desacreditar el concepto de necesidades. Pero las malas aplicaciones de un concepto no lo hacen desaparecer.

${ }^{20}$ En el análisis que he realizado en mi columna "Economía Moral", en La Jornada, del libro de Leiss, he señalado, por lo que se refiere a la confusión del consumidor contemporáneo, entre otras cosas, lo siguiente: "Los anteriores problemas [la inadecuación del conocimiento individual sobre los bienes, el peligro de daños personales físicos y psicológicos derivados de su uso, y la escasez creciente de tiempo para el consumo ante la masa creciente de bienes], dice Leiss, dan lugar a la confusión de los individuos acerca de la naturaleza y objetivos de sus apetencias que no puede ser explicada solamente por la influencia de la publicidad, aunque ésta constituye un factor decisivo. Las imágenes
La mayor parte de los escritores utopistas se involucran con la satisfacción de las necesidades. La buena sociedad es aquella en la cual las necesidades verdaderas son satisfechas y que no permite la intrusión de 'falsas' necesidades que creen insatisfacción [...] En alguna medida al menos, la ansiedad sobre la manera en que las sociedades ficticias, utópicas o antiutópicas, crean miembros que no experimentan necesidades que la sociedad no puede enfrentar está fuera de lugar. Tanto la noción de manipulación como la de 'educación del deseo' (una preocupación imputada a Morris que se ha puesto de moda recientemente ${ }^{21}$ ) implica un núcleo de necesidades/apetencias que trasciende el contexto social y que, si no se distorsiona o reprime, puede usarse como poder transformador.

La razón de esto es que parecemos estar enfrentados a un serio dilema. O bien afirmamos la existencia de necesidades humanas básicas o bien parecemos carecer de criterios para evaluar sociedades más allá del grado de ajuste que logran entre necesidades que ellas mismas construyen y los medios que proveen para su satisfacción. La última postura se percibe intuitivamente como insatisfactoria. Sin embargo, el dilema está mal planteado. La apelación a las necesidades es ideológica en la medida en que la atribución de

utilizadas en la construcción de los mensajes publicitarios con frecuencia incorporan un conjunto de ambigüedades acerca de las apetencias y sus objetivos, dice Leiss. Es evidente que este autor percibe como sumamente débiles a los individuos y como muy poderosa a la publicidad. Como riesgo psicológico central, Leiss sostiene que 'cada aspecto de las necesidades de una persona tiende a fragmentarse en partes componentes cada vez más pequeñas, y que por tanto se vuelve cada vez más difícil para la persona integrar los componentes en un conjunto coherente de necesidades y una estructura de personalidad coherente'. Ejemplifica esta fragmentación con la necesidad de respeto propio, para responder a la cual los individuos cultivan ciertas disposiciones internas o rasgos de personalidad y también ajustan su apariencia externa de acuerdo con cambiantes normas sociales. Aquí Leiss parece asumir como el comportamiento humano normal lo que Fromm ha llamado el carácter mercantil y que caracteriza en los siguientes términos: "La orientación del carácter que está enraizada en la vivencia de uno mismo como mercancía y del valor propio como valor de cambio". Fromm considera este carácter como la deformación más grave que en la personalidad humana causa el capitalismo. Como la personificación de la alienación misma. Leiss, en cambio, parece asumir ese consumidor de manera acrítica. Además supone que todos los individuos reaccionan así, mientras que para Fromm sólo reaccionan así las personas dominadas por el carácter mercantil, que no son la mayoría. Quien tiene un propósito vital claro usa las mercancías como apoyo para lograrlo y no estará ansiosamente tratando de captar cuáles son ahora los gustos sociales para adaptarse a ellos en su búsqueda de aprobación.

${ }^{21}$ Ruth Levitas, como lo comprobará el lector de la sección Legados de este número de Desacatos, cambió su actitud sobre la "educación del deseo" al punto de titular así el capítulo de su libro The Concept of Utopia. 
naturalidad es usada para evitar, disfrazar o negar la necesidad de elegir entre formas de organización social con base en valores, en oposición a una medición objetiva de su virtud ${ }^{22}$.

Las utopías hacen afirmaciones sobre las necesidades, en el sentido de traducir a términos concretos necesidades físicas y de sobrevivencia abstractas y de postular otras ne-

${ }^{22}$ Hay aquí un planteamiento muy importante sobre la relación entre necesidades $y$ valores, sobre el cual habría mucho que discutir. Levitas tiene razón al decir que para huir de los juicios de valor muchos autores se refugian en la naturalidad de las necesidades, como ocurre con la socio-biología que ella critica con dureza en el trabajo que venimos citando. La discusión remite, por una parte, a la naturaleza de las necesidades. Necesidad es un concepto tanto empírico como normativo, en el que ambos elementos están embrollados. El concepto de daño que resulta de la insatisfacción es evidentemente empírico, pero de un empírico embrollado. Por ejemplo, para observar las neurosis y psicosis que resultan de la insatisfacción temprana de ciertas necesidades se requiere una mezcla de evaluación y descripción. Es decir, que según esta concepción, la relación entre necesidades y valores es una relación interna al propio concepto de necesidades. En varias teorías de las necesidades se ratifica. Doyal y Gough rechazan la concepción de las necesidades como impulsos y adoptan la de propósitos. Maccoby ha formulado su concepción de las necesidades sin usar este término, sino el de impulsos-valores, relacionado con la concepción de Max Neef et al., quienes han dicho que "las necesidades patentizan la tensión constante de los seres humanos entre carencia y potencia". Maccoby ha dicho que: "Un enunciado de necesidad siempre puede transformarse en un enunciado de valor. Si yo digo 'necesito algo', pregúntenme qué pasará si no lo consigo. La respuesta 'me sentiré solitario, menos capaz, humillado', describe un valor: sociabilidad, maestría, dignidad. Incluso lo inevitable (necessity) (necesito sobrevivir) expresa el valor universal de la vida" (Michael Maccoby, Why Work? Motivating and Leading the New Generation, Simon and Schuster, Nueva York, 1988, p. 56). Para Levitas parecería que los valores pueden estar al margen de las necesidades, que pueden postular incluso la negación o represión de las necesidades y, aunque ello ha ocurrido históricamente en muchas sociedades, particularmente con la necesidad sexual, la postura de Maslow y de Fromm es siempre la de unir valores y necesidades. Pero el planteamiento más consistente es el de Márkus, quien después de sostener la que habría de convertirse en idea clave de Ampliar la mirada -que el "Principal criterio de desarrollo histórico es para Marx la medida en la cual se constituyen los presupuestos de un desarrollo irreprimido y rápido de las fuerzas esenciales humanas, capacidades y necesidades, y del despliegue de la individualidad humana libre, multilateral, o sea, la medida en la cual se actúan esos presupuestos, la medida en la cual se realiza el 'ser humano' [la esencia humana] en la existencia individual concreta" - expone una concepción radical de los valores: "Sólo así es posible estimar de un modo universalmente válido, y al mismo tiempo ético-axiológico, las varias épocas y manifestaciones de la historia, no sobre la base de un orden axiológico suprahistórico, trascendente, sino de acuerdo con una caracterización objetiva, histórico-inmanente - $\mathrm{y}$ al mismo tiempo universalmente válida - de la evolución humana. Marx considera valores humanos los momentos de la evolución humana que expresan y promueven subjetiva u objetivamente ese despliegue y esa realización del ser humano". Los valores del florecimiento humano son el desarrollo y satisfacción de necesidades y el desarrollo y aplicación de capacidades. Los valores están inextricablemente unidos al desarrollo de las fuerzas esenciales humanas. cesidades (sociabilidad [conviviality], creatividad, autorrealización); y hacen afirmaciones acerca de la mejor manera de satisfacer estas necesidades. Al hacerlo, sin embargo, no proceden, y no deben hacerlo, de los elementos biológicos dados a las 'necesidades' y a las 'satisfacciones'. Hacer eso sería tratar como secundarias las necesidades emocionales y simbólicas, adoptar una jerarquía precisamente en la manera en la que Leiss ha argumentado que resulta inapropiado por la entremezcla de las esferas materiales y simbólicas de la cultura humana ${ }^{23}$; y haría un sin sentido la frecuencia con la cual los individuos y los grupos eligen dejar de lado la seguridad, la comodidad o la sobrevivencia física por el interés del altruismo o del respeto propio ${ }^{24}$.

${ }^{23}$ Dada la identificación incorrecta que hace Levitas de las necesidades inferiores de Maslow (a quien se refiere Leiss) como básicas (y naturales) y las superiores como no básicas (y no naturales), se explica el texto en cursivas. Para Maslow las necesidades superiores no son secundarias en una escala axiológica; por el contrario son las que distinguen al ser humano de las otras especies. Pero son menos prepotentes en el sentido de que una persona con todas las necesidades insatisfechas quedará dominada por las necesidades bajas, las fisiológicas y las de seguridad.

${ }^{24}$ A una crítica muy similar de Len Doyal e Ian Gough a Maslow (que dice que los alpinistas parecen más preocupados por su autorrealización que por su seguridad, lo que haría falsa la supuesta secuencia temporal estricta de la jerarquía) contesté de la siguiente manera en Ampliar la mirada: "el ejemplo usado (del alpinista) conlleva una falacia. Los escaladores de montaña no son personas que vivan con la necesidad de seguridad insatisfecha permanentemente. No son espías en territorio enemigo. Cuando escalan, pagan el precio de la inseguridad para llevar a cabo la actividad en la que se sienten felices o realizados, lo cual en mi opinión es una cuestión distinta" (sección 3.8, "Críticas a las teorías de Maslow"). Me parece que es el mismo caso del que, por razones religiosas o de salud, ayuna. En ambos casos se deja insatisfecha voluntariamente y de manera temporal una necesidad inferior (alimentación, seguridad) para alcanzar otra que puede ser superior. En una sección de Motivation and Personality (Addison-Wesley Longmann, Nueva York, 1987 [1954], pp. 26-27) sobre las excepciones a la jerarquía de necesidades, Maslow se anticipó a ésta y a otras críticas. De mi relato de este asunto en Ampliar la mirada son las siguientes frases (lo entrecomillado son palabras textuales de Maslow): "Tendemos a subvaluar las necesidades siempre satisfechas, lo que lleva a algunos a ponerlas en riesgo en defensa de necesidades más elevadas. Sin embargo, la experiencia puede revalorar las necesidades más prepotentes". Maslow da un ejemplo hipotético: "un hombre que ha renunciado a su trabajo por conservar el respeto a sí mismo, y que pasa hambre por seis meses, puede estar dispuesto a volver a su trabajo aun al precio de perder su autorrespeto". "La tesis de la jerarquía ha sido enunciada en términos de deseos conscientemente percibidos y no en términos de conducta". Lo que he sostenido, señala Maslow, es que "la persona carenciada en dos necesidades básicas querrá, deseará, la más prepotente. Muchas reversiones aparentes de la jerarquía, que se observan en la conducta, no necesariamente lo son en los deseos, ya que en la conducta influyen otros factores". 


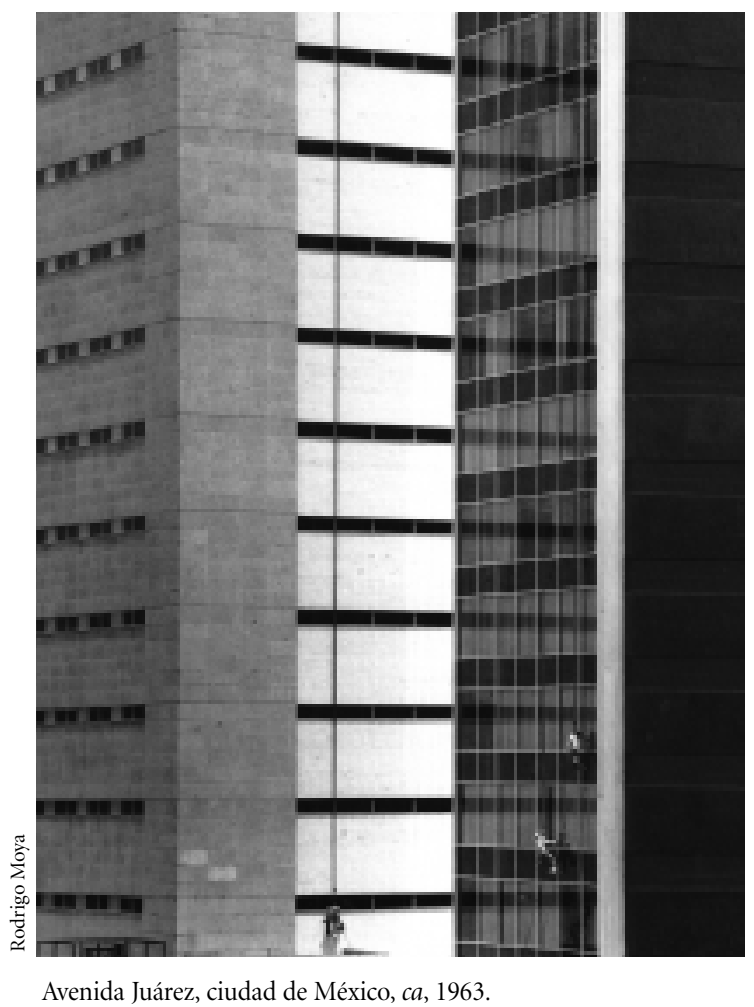

Aquí termina el texto extractado de Levitas. Mis observaciones en las notas al pie de página expresan el diálogo con la autora. Es un diálogo amistoso pero duro. Lo que está en juego es muy importante. Aunque Levitas, como Leiss, no rechaza el concepto de necesidades humanas del todo, sí rechaza su carácter universal e igualan necesidades y apetencias. Coincido plenamente con Doyal y Gough, quienes en su férrea batalla en defensa de las necesidades humanas universales, han dicho que el rechazo de la existencia de necesidades humanas comunes y "la creciente consideración de las necesidades humanas como concepto subjetivo y culturalmente relativo" constituyen una "creencia que ha contribuido al predominio intelectual de la nueva derecha". Porque si la noción de necesidades humanas objetivas carece de fundamento, entonces ¿qué alternativa queda sino creer que los individuos saben mejor que nadie lo que es mejor para ellos mismos y alentarlos a perseguir sus propias metas subjetivas o preferencias? ¿Y qué mejor mecanismo hay para ello que el mercado? El desplazamiento de las necesidades a las preferencias permite justificar plenamente el dominio del mercado sobre la política" (Len Doyal e Ian Gough, A Theory of Human Need, Macmillan, Londres, 1991, pp. 1-2, énfasis añadido).

\section{MIRADOR ICONOCLASTA}

"El florecimiento humano como mirador iconoclasta ante la mundialización de la pobreza" de Luis Arizmendi (de aquí en adelante Mirador iconoclasta) es un formidable ensayo sobre la mundialización de la pobreza que concluye con una sección en la que ubica el enfoque de Ampliar la mirada (y sus antecedentes) como mirador iconoclasta de dicha mundialización. El autor comienza señalando que la tercera gran crisis del capitalismo, junto con tres elementos de "contratendencia" que el capitalismo implementó para contrarrestar la crisis (la derrota de los monopolios defensivos del tercer y del segundo mundos, la configuración neoliberal del Estado, y la revolución tecnológica) conforman los dispositivos que marcan una de las peculiaridades de la fase actual del capitalismo: la mundialización de la pobreza. Mirador iconoclasta analiza los tres dispositivos. En la primera sección hace notar, en primer lugar, cómo a partir de los ochentas, pero sobre todo de los noventas, la pobreza mundial pasa a ocupar un lugar estratégico en la agenda de los organismos internacionales, particularmente del Banco Mundial (BM). Arizmendi tiene la lucidez para percatarse de que esto debe verse como polo complementario de la configuración neoliberal del capitalismo contemporáneo, cuyo propósito no es la superación de la pobreza sino contener estratégicamente a los pobres para neutralizar potenciales riesgos de inestabilidad. Agudamente, percibe que las funciones reales del umbral de pobreza que define el BM (que reconoce como pobre sólo a quien no puede adquirir siquiera los alimentos crudos mínimos) van más allá del menoscabo de la auténtica magnitud de la pobreza mundial y consiste en la revelación de que "la sociedad global de ningún modo puede ni debe asumir ofrecer acceso al bienestar a las mayorías, tiene que admitir como inevitable un desdoblamiento y una polarización radical 
[... ] y garantizar a los excluidos exclusivamente el derecho a la sobrevivencia puramente física o animal".

De esta manera, Arizmendi ha conectado la tarea, aparentemente tecnocrática de la definición de líneas de pobreza, con uno de los rasgos centrales de nuestra época: "el mirador del Banco Mundial sintetiza o expresa la identidad histórica de una nueva fase de la mundialización capitalista: la fase actual que tiene su especificidad precisamente por ser una mundialización capitalista cínica”. Cínica, continúa el texto de Mirador iconoclasta citando a Bolívar Echeverría, "porque admite sin vacilaciones sus efectos depredatorios contra el proceso de reproducción social y se formula su funcionalización opresiva". La forma cínica del capitalismo requiere la reconfiguración neoliberal del Estado y el traslado autoritario de la máxima autoridad al capital. Naturalmente, el cinismo es recubierto con el mito de la globalización como "proceso puramente benéfico de difusión mundial del progreso" y el discurso del BM, dice Arizmendi, "oscila entre el cinismo y la mistificación porque, aunque su proyecto de la administración de la pobreza mundializada es innegablemente cínico, insiste en que su estrategia económica globalizadora genera progreso". La primera sección de Mirada iconoclasta termina poniendo al descubierto una "doble yuxtaposición demagógica que articula: 1) la identificación de globalización con crecimiento económico y, sobre ella, 2) la identificación de crecimiento económico con reducción de la pobreza", cuya función es encubrir las formas actuales de apuntalamiento del poder planetario por una tendencia hacia la globalización de la riqueza.

En la segunda sección, al tiempo que analiza cada uno de los dispositivos puestos en juego para contrarrestar la crisis, Arizmendi irá replicando a esta doble yuxtaposición demagógica del BM. La derrota de los monopolios defensivos erigidos por los Estados-nación del primer y del segundo mundos — caracterizados en Mirador iconoclasta como un doble monopolio que, por un lado, puso bajo la subordinación del capital nacional la fuerza de trabajo y, por el otro, bajo la propiedad del Estado-nación sobre los recursos naturales estratégicos- supuso el derrumbe del nacionalismo y la desindustrialización seguida de una reindustrialización dentro de la nueva forma de subordinación tecnoeconómica ante los capitales metropolitanos. La irrupción de América Latina y de los países del este europeo en las nuevas formas de la globalización no generó crecimiento económico, desmintiendo la primera parte de la doble yuxtaposición demagógica del BM. Arizmendi, siguiendo a Chossudovsky, aborda la estrategia en dos etapas, estabilización y reformas estructurales, adoptada por el BM. Sostiene que la primera desestabiliza el mercado interno para que la segunda impulse el apoderamiento y la recomposición de la base industrial de su capital productivo estratégico. La ausencia de autodeterminación nacional, concluye Arizmendi, se convierte en fundamento de un ominoso oleaje mundializado de empobrecimiento.

Arizmendi replica a la segunda yuxtaposición demagógica del BM señalando que en la fase actual de la mundialización capitalista crecimiento económico y reducción de la pobreza no corren paralelos pues, a diferencia del estado liberal y del keynesiano que intentaron acompañar el crecimiento económico con la elevación del estándar nacional de vida, la reconfiguración neoliberal del Estado asumió como uno de sus ejes la represión del salario tanto directo como indirecto. La lucha contra la inflación, señala, fue la cobertura funcional de la represión del salario directo. Esta primera represión se complementó con una táctica en dos vías para reprimir el salario indirecto: la privatización directa de los servicios educativo y médico o, cuando la correlación de fuerzas no permitía la vía anterior, el desfinanciamiento estratégico programado de los servicios públicos que empuja a la sociedad nacional al consumo de servicios privados ${ }^{25}$. La represión salarial persiste más allá del periodo de crisis y determina que la reducción de la pobreza no acompañe al crecimiento económico.

Mirada iconoclasta, al abordar el tercer dispositivo para contrarrestar la crisis, la revolución tecnológica, destaca que la teleinformática permite la articulación a dis-

\footnotetext{
${ }^{25}$ Arizmendi cuenta cómo el estreno mundial de esta estrategia se da en Chile con el gobierno militar que asesinó a Allende; cómo lo primero que hizo el gobierno fue triplicar el precio del pan y contener los salarios, lo que dio el banderazo de salida de la ofensiva internacional contra los salarios. ¿̇erá casual que uno de los primeros resultados de la gestión de Calderón en México sea la duplicación del precio de la tortilla al mismo tiempo que, también, se congelan los salarios?
} 
tancia en tiempo real del proceso productivo, lo que dota de una movilidad internacional acrecentada al capital, que refuerza su poder para confrontar a la fuerza de trabajo fragmentada, sin movilidad internacional, fortaleciendo así la represión salarial en todo el mundo. Presenta una periodización de la sobreexplotación capitalista (articulación de explotación de plusvalor con expropiación de valor al salario, sustracción de recursos del fondo social de consumo): 1) Sobreexplotación concentrada en la metrópoli (1740-1880). 2) Sobreexplotación concentrada en la periferia (1880-1970/1980), en el cual se desactiva la sobreexplotación metropolitana y se traslada al capital periférico que, obligado "a una cesión crónica [un tributo] de enormes masas de valor y plusvalor" por la supremacía tecnológica e instrumental del capital metropolitano, responde duplicando la explotación de la fuerza de trabajo periférica (trasladando el pago del tributo a los trabajadores). La sobreexplotación se convierte en dispositivo permanente del capitalismo periférico. 3) Sobreexplotación planetaria del trabajo (a partir de 1980) ya que no sólo se recrudece ésta en la periferia sino que se reinstala en la metrópoli. Esta etapa genera lo que Arizmendi llama el Cuarto Mundo, que incluye por igual zonas de las periferias y de las metrópolis. Explica el papel de la biotecnología en la pauperización de la producción campesina y en la expropiación de recursos naturales.

Arizmendi sostiene que la mundialización contemporánea de la pobreza "ha llegado tan lejos que ha abierto el choque de dos tendencias contrapuestas que pugnan por la definición de la configuración histórica del capitalismo para las siguientes décadas". Una neofascista continuación de la mundialización capitalista cínica que viene empujando por la reedición del fascismo a escala planetaria. Frente a esta tendencia dominante, surge una de resistencia, neokeynesiana, en la que ubica a Joseph Stiglitz, y que busca reactualizar el proyecto del Estado regulador interventor en la economía para moderar los efectos destructivos sobre el proceso de reproducción social.

"En una era así, la construcción de un horizonte crítico transcapitalista en la conceptualización de la pobreza contemporánea se ha convertido en una imperiosa necesidad", concluye Arizmendi, creando así un enlace con la tercera sección de su artículo que analiza no sólo Am- pliar la mirada, sino lo que él llama las tres etapas del desarrollo de mi proyecto crítico de la pobreza, el análisis del cual lo organiza en torno a cuatro principios (totalidad, transdisciplinariedad, economía moral y soberanía) que, según su lectura, caracterizan mis contribuciones al debate mundial sobre el tema. Arizmendi identifica las tres etapas mencionadas como sigue: 1) "La fundación de una nueva mirada: el proyecto de estudio de la pobreza en clave de valor de uso", en la cual se esboza la implementación del principio de la totalidad. 2) "El proyecto fundacional del método de medición integrada de la pobreza (MMIP): la pobreza económica total y la libertad como necesidad económica”, en la cual se redondea la aplicación del principio de la totalidad, "se unifica en una misma totalidad el conjunto global de dimensiones que determinan la base material del proceso de reproducción social" y se "descubre la importancia del tiempo libre para la conceptualización de la pobreza". 3) "Ampliar la mirada: el proyecto de crítica a la pobreza desde la riqueza humana total y la libertad como necesidad histórica", en la que "se parte de una concepción del ser humano como totalidad, es decir, del reconocimiento de su sistema total de necesidades para "transitar del sistema total de necesidades económicas al sistema total de necesidades y capacidades individuales y sociales como fundamento del florecimiento humano", y en el cual "el tiempo libre adquiere toda su fuerza como plataforma histórica imprescindible para el pleno despliegue multifacético de las potencialidades humanas".

Arizmendi señala que mi proyecto, al "colocar el florecimiento humano como mirador, tiene que asumir la aventura de crear una mirada transdisciplinaria". Y añade: "Porque el ser de la humanidad constituye una totalidad también tiene que constituirla su saber". Describe dos tareas centrales de Ampliar la mirada: "la edificación de los soportes del florecimiento humano como mirador" y la "crítica a la reducción economicista". Describe mi rechazo a la dicotomía hechos/valores que concibe, con justa razón, como una de las raíces del horizonte del concepto de economía moral, acuñado por el destacado historiador británico E. P. Thompson, cuya aguda visión le permitió percibir que "el valor de uso (el bien) que rige el proceso de reproducción social de una época" (el 
pan en la Inglaterra del siglo XVIII, la tortilla en el México de hoy) "constituye un fundamento con el que siempre se correlaciona la noción social del bien moral que se erige en ella". Brillantemente concluye Arizmendi que "pensar en clave de valor de uso exige pensar inmediatamente en clave normativa". Cierra este inciso de Mirada iconoclasta la siguiente reflexión: "Si existe una época en la que, a todas luces, la formulación del 'objetivismo puro' o 'neutro' revela su complicidad con el poder moderno, es ésta en la que ante la mundialización de la pobreza el cinismo histórico intenta recubrirse con aquél".

El ensayo de Arizmendi termina con el inciso referido a la soberanía en el que recupera los planteamientos que recientemente he venido haciendo sobre "la necesidad de articular el proyecto de la autodeterminación nacional con la generación de masas críticas mínimas de capacidades tecnológicas como de capacidades sociales" y los vincula con mis planteamientos sobre la desmercantilización, coincidentes con los de Esping-Andersen pero también, como lo muestra Arizmendi, con los de Wallerstein.

\section{MIRAR EL TIEMPO PARA FLORECER}

El artículo "El tiempo necesario para el florecimiento humano. La gran utopía” de Araceli Damián (de aquí en adelante Mirar el tiempo para florecer) aborda de manera crítica un aspecto central de las condiciones previas para el florecimiento humano, el tiempo libre, contribuyendo al desarrollo conceptual del nuevo enfoque planteado en Ampliar la mirada. Además, plantea la crítica pregunta de si es posible el florecimiento humano en el marco de las relaciones capitalistas de producción. En la introducción la autora adelanta una de las conclusiones centrales a las que llega — siguiendo a Gianni Toti, quien no habla de florecimiento humano sino de la unificación del tiempo libre y el tiempo de trabajo (trabajo que deja de ser trabajo para ser actividad creadora y, por tanto, transforma el tiempo en tiempo de libertad), que equipara al de florecimiento- : que la eliminación de las clases sociales es condición indispensable de tal unificación, y por tanto del florecimiento humano, ya que en la so- ciedad de clases la alienación invade no sólo el trabajo sino también el tiempo libre. El análisis de la alienación contemporánea en el tiempo libre es un complemento fundamental del análisis de la alienación del trabajo. La autora hace notar que Toti (a pesar de lo dicho antes) y Maslow consideran que en las sociedades actuales algunos individuos logran excepcionalmente condiciones de creatividad o de autorrealización, con lo cual también concuerda Sebastian de Grazia, autor con el que introduce el concepto de ocio en su sentido filosófico clásico: actividad musical y de contemplación (teorizar y filosofar). El carácter elitista del florecimiento humano posible en el capitalismo le da mucho sentido a las preguntas que formula Damián: si esto es prueba de que no están dadas las condiciones para el florecimiento de la mayoría, si el tiempo libre puede conducir al florecimiento humano, y por qué éste no ha alcanzado a una proporción mayor de la población a pesar de la reducción de la jornada de trabajo. A partir de estas preguntas define los propósitos de Mirar el tiempo para florecer: abordar la determinación de la duración de la jornada laboral en el capitalismo, incluyendo las luchas obreras; la forma cómo el capitalismo transforma la vida del trabajador, produciendo una escisión entre el tiempo de trabajo y el tiempo libre; cómo, dada la apropiación privada de los medios de producción, la fragmentación del proceso productivo conlleva a un desencanto por el trabajo en el obrero (o sensación de vacío), que se traslada al tiempo libre.

En la primera sección de Mirar el tiempo para florecer podemos leer que "la generalización de las relaciones capitalistas de producción conllevó a la imposición de jornadas laborales extremas, en las que se llegó literalmente a la apropiación de todo el tiempo de vida de los trabajadores"; podemos leer las descripciones que hace el historiador británico E. P. Thompson de las resistencias de la población a este intento de apropiación total y las quejas de los empresarios; también leer los relatos, a través de citas de Marx, E. P. Thompson y otros, de las drásticas medidas que se implementaron para vencer esa resistencia: aumento de impuestos, aumento en los precios de las subsistencias y reducción de los salarios; nos enteramos cómo la fuerza de trabajo "tuvo que ser obligada a ajustarse a los tiempos de la producción mecanizada”; cómo el ca- 
pital arremetió violenta y desmesuradamente para extender la jornada laboral durante el último tercio del siglo XVIII; en síntesis, nos enteramos cómo se consideró "todo el tiempo de un individuo como tiempo de trabajo, degradándolo, por consiguiente, a mero trabajador"; "cómo se domesticó y utilizó la fuerza de trabajo desde la niñez".

A continuación Mirar el tiempo para florecer analiza las luchas por la reducción de la jornada de trabajo, identificando los hitos que llevaron a la jornada de diez horas y luego, en las primeras décadas del siglo XX, a la de ocho horas. Cabe aquí añadir que la jornada máxima de ocho horas durante seis días a la semana quedó instituida formalmente en México en la Constitución de 1917, pero que tuvo su primer antecedente en el Programa del Partido Liberal que en 1906 proclamó ésta y muchas otras reformas para moderar la explotación de los trabajadores. La autora analiza, con datos recientes de la Organización Mundial del Trabajo (OIT), los valores promedio de las jornadas semanales en diversos países del mundo y muestra que si bien en algunos países prevalecen jornaex tercer mundo hay países con jornadas promedio extremas. Los datos de Egipto y los ejemplos de Chile y China que narra parecen confirmar (sobre todo si se analizan a la par de las tendencias del salario directo e indirecto), como hemos visto en el artículo de Arizmendi, la presencia de una nueva etapa de la sobreexplotación del trabajo a escala mundial.

La siguiente sección argumenta, con apoyo en E. P. Thompson, que con la generalización de las relaciones sociales capitalistas de producción el trabajador experimenta (objetiva y subjetivamente) una escisión entre la vida y el trabajo. De la orientación del tiempo por tarea de las sociedades precapitalistas se pasa al trabajo cronometrado en el capitalismo; del control de su propia vida laboral, al control por parte del capital. Siguiendo a De Grazia muestra cómo la producción en serie no sólo trasladó a hombres, mujeres y niños de la libertad de los talleres y casas y los puso bajo los techos de las fábricas, sino que debilitó la socialización. La consecuencia más general para el trabajador es que "su trabajo deja de estar entrelazado con su vida" pues ambas se desarrollan en

temporalidades (y espacios) diferentes. Por tanto, concluye Damián, el ser humano se escinde. La sección termina con un análisis, que se apoya en Márkus, de la importancia de la socialización que el capitalismo debilita, ya que en ella se transmiten normas éticas, sociales y de uso de los objetos producidos por el hombre.

Mirar el tiempo para florecer continúa con dos secciones dedicadas, sucesivamente, al análisis de la alienación en el trabajo y en el tiempo libre y sus consecuencias en términos de posibilidades de florecimiento humano. Damián empieza mostrando cómo, en contraste con la concepción de Marx de la esencia del trabajo específicamente humano ("lo que distingue al peor maestro albañil de la mejor abeja es que el primero ha modelado la celdilla en su cabeza antes de construirla en la cera") el capitalismo le quita al obrero la posibilidad de orientar su voluntad a un fin, lo hace perder, respecto del artesano, la visión y el control del proceso de producción en su conjunto. También muestra, citando a Márkus, cómo el trabajador siente la fuerza colectiva del trabajo (controlada por el capital) como un poder ajeno, y cómo el trabajo pierde la esencia que lo distingue como actividad específicamente humana, su carácter de actividad orientada a un fin; pierde su carácter auto-activo, deja de formar multilateralmente al sujeto y de desplegar libremente la capacidad de éste y, por el contrario, se convierte en actividad constrictiva externa que deforma y unilateraliza. Pero Damián muestra, también, cómo para Marx y Márkus la alienación, entendida como fase transitoria, desempeña funciones positivas, creadoras: la disolución de las comunidades locales mezquinas y la riqueza objetual de las necesidades y capacidades humanas, que ambos autores consideran presupuestos objetivos de la emancipación humana. $D a-$ mián expresa su duda de si esa riqueza objetual conducirá a la emancipación y el florecimiento humanos. Pasa entonces a analizar la visión de Toti y de De Grazia al respecto. La visión del segundo (es lo impersonal del tiempo lo que aburre al trabajador) es confrontada con las críticas de Toti a quienes han identificado las cuestiones técnicas como el origen del problema, pues para él, el origen hay que buscarlo en las relaciones sociales de producción.

Esta afirmación de Toti, sin embargo, tiene problemas. Además de no presentar argumentos para sostener 
tal tesis, que por tanto puede interpretarse como una postura ideológica (es el capitalismo el origen del problema, por lo cual en el socialismo realmente existente de los años setenta, a pesar de un modelo industrial similar, no habría el mismo problema). Si se analiza la cita larga que Damián hace de Márkus se verá que éste identifica la división espontánea del trabajo y la propiedad privada como los factores explicativos de diversas dimensiones de la alienación y que si se aceptara esta visión como correcta habría que precisar cuáles son las condiciones de apropiación del producto (relaciones sociales de producción) y de organización del trabajo (fuerzas productivas) que garantizarían la superación de la alienación. Toti formula la pregunta, pero no la responde, sobre las reacciones físicas y mentales de millones de trabajadores soviéticos ante sus respectivos trabajos fraccionados, los trabajos en cadena. Me parece que no basta la propiedad colectiva o cooperativa, y mucho menos estatal, para eliminar todas las condiciones del trabajo alienado. Un rayo de esperanza se puede encontrar en la esencia de la revolución científicotécnica en marcha desde hace medio siglo que trataré después de terminar la reseña del artículo de Damián, que aborda ahora la alienación en el tiempo libre.

Mirar el tiempo para florecer permite leer que la necesidad del tiempo libre en la clase obrera surge en la medida en que avanza la apropiación de todo el periodo activo de la vida del trabajador por parte del capital, escindiendo los espacios de la vida y el trabajo; que los capitalistas veían con malos ojos el tiempo libre ganado por la clase trabajadora, ya que lo consideraban la madre de todos los vicios, o tiempo para la concientización obrera; que en el tiempo libre ganado, sectores obreros fundaron escuelas, salas de lectura, y que ante ello la burguesía sustrajo del control del movimiento reformador un cierto número de institutos de cultura obrera; que el capital desarrolló una industria del tiempo libre que transforma al ciudadano en una termita consumidora permanente; que la ideología concurrente sostuvo que la fuerza de trabajo no debe pasar el tiempo libre, no debe desperdiciarlo, sino consumirlo, usarlo, gastarlo; que al momento de ganar el tiempo libre éste ya había perdido todo significado y era identificado con el aburrimiento y que, por tanto, era necesario organizar la gran matanza del tiempo libre (es decir, la

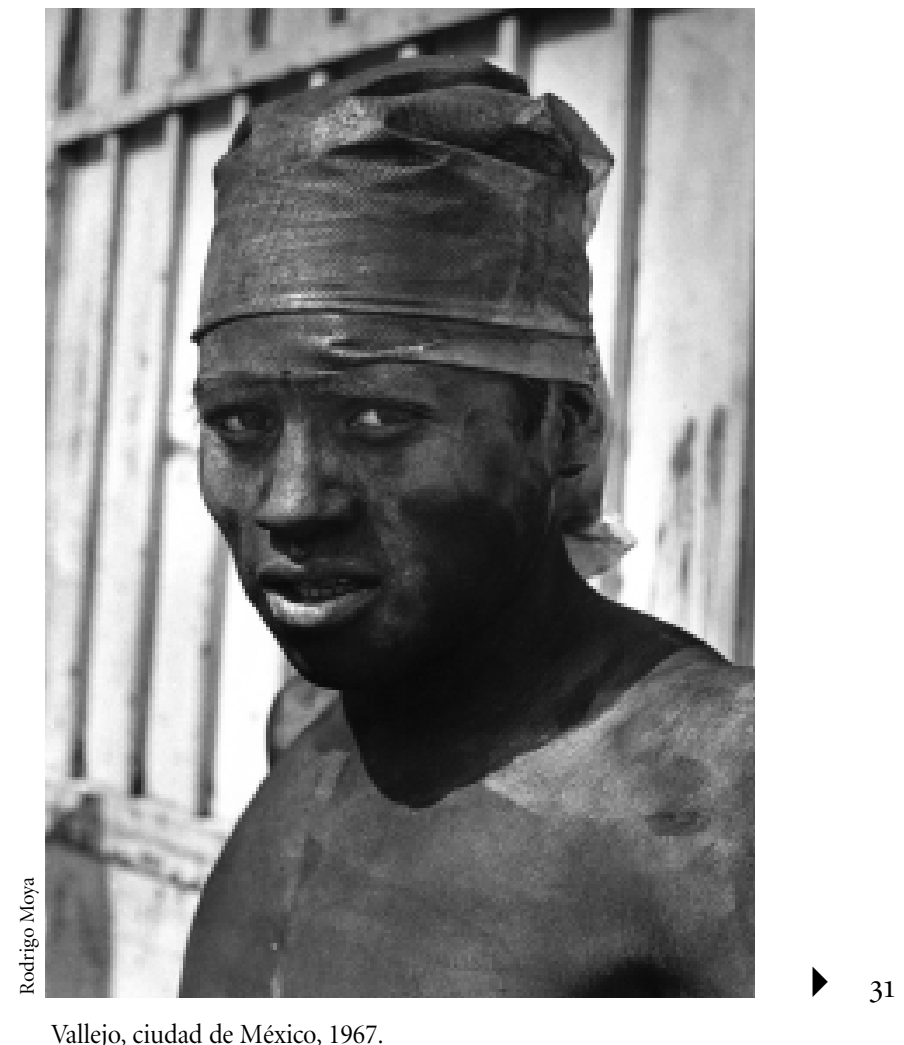

matanza de la vida); que el tiempo libre se usa para comprar y consumir y, crecientemente, en el transporte; que lo que sobre se use en el entretenimiento dominado por la televisión, en actividades sin pensamiento; y que "el florecimiento humano no puede realizarse durante el tiempo dedicado a las actividades sin pensamiento, de diversión o de fuga, ya que aquél requiere del intelecto".

Damián retoma las consecuencias del trabajo fragmentado y enajenado en la atrofia de las capacidades humanas, particularmente de las intelectuales, citando al efecto a Adam Smith y a Engels. A pesar de que algunos individuos puedan sobreponerse a las limitaciones que el modo de producción impone para lograr el florecimiento humano, la inmensa mayoría busca su libertad en las actividades del entretenimiento de masas. De esta manera, la idea de tiempo libre se impone sobre la de la libertad para el propio desarrollo, señala. El tiempo libre aparece como un vacío por llenar y el aburrimiento no logra ser supe- 
rado mediante el entretenimiento. Por ello Toti, dice la autora, sostiene que lo que hay que hacer es devolverle al tiempo libre, que ha sido convertido en mercancía, su significado, transformándolo en tiempo de conciencia, de lucha para librarse del trabajo. Mirar el tiempo para florecer termina con pesimismo: "Cada día aparece más remota la posibilidad de que el trabajador logre trascender el grado de alienación en el que se encuentra y encuentre el camino al florecimiento humano". La autora plantea como necesarias dos condiciones, apoyándose en Márkus y en Marx: la transformación de las relaciones sociales de producción, para que las fuerzas productivas sociales cesen de ser "fuerzas del capital independizadas frente al trabajador" $y$ "en contraposición a su propio desarrollo"; y la abundancia, que le permita al ser humano la "indiferencia hacia los problemas de la propiedad de los medios de producción".

\section{UNA MIRADA ESPERANZADORA}

En mi opinión, sería necesario añadir a esto último la transformación del trabajo en trabajo creativo. Es éste el aspecto, derivado de la revolución científico-técnica, que más destacan Richta et al. en La civilización en la encrucijada ${ }^{26}$. Por su importancia, y porque complementa de manera importante no sólo el artículo de Damián sino todos los trabajos temáticos de este número de Desacatos, en el cual no se ha tratado de manera sistemática la

\footnotetext{
${ }^{26}$ La civilización en la encrucijada, Artiach, Madrid, 1972, pp. 35-38, edición original en checo, 1968. Hay otra edición en español (con otra traducción) de Siglo XXI. Esta obra fue elaborada por "el equipo multidisciplinario, encabezado por Radovan Richta, del Instituto de Filosofía de la Academia de Ciencias de Checoslovaquia" y, como dicen ellos mismos (en "Introducción a las ediciones extranjeras" firmada en Praga, en la primavera de 1968), "la redactamos en medio de un clima profundamente crítico, polarizado por una discusión encarnizada sobre las vías de desarrollo de una sociedad que ha alcanzado su madurez industrial después de un periodo de transformaciones socialistas radicales". La investigación de la que derivó el libro fue resultado de una decisión del Comité Central del Partido Comunista de Checoeslovaquia. Pocas veces un comité formado por órdenes públicas produce un informe de tanto valor. Probablemente se trata de uno de los testamentos más lúcidos de lo que podría haber sido otra vía para el futuro de la humanidad si los tanques soviéticos no hubiesen reprimido la humanamente floreciente primavera de Praga.
}

dimensión tecnológica ${ }^{27}$, a pesar de su centralidad en el florecimiento humano, la pobreza, la utopía y la teoría crítica, a continuación expongo algunas ideas centrales de esta brillante obra. Los autores describen así la esencia de la revolución científico-técnica:

A lo largo de las últimas décadas, el desarrollo impetuoso de la ciencia y la técnica ha comenzado a desbordar los límites de la revolución industrial [...] Los instrumentos de trabajo superan por su desarrollo los límites de las máquinas mecánicas y asumen funciones que los convierten, en principio, en complejos autónomos de producción [...] el aspecto subjetivo de la producción, invariable durante siglos, se modifica: desaparecen progresivamente las funciones de la producción directa realizadas por la fuerza de trabajo simple; la técnica va suplantando al hombre en las funciones directas de ejecución, de manutención, de manipulación y, finalmente, de regulación [...] La originalidad del aún incipiente movimiento, lo que [...] lo define como revolución científico-técnica, está en que [...] sacude toda su estructura elemental al modificar radicalmente el lugar ocupado por el hombre. Su originalidad consiste en [...] asegurar el triunfo del principio automático en el más amplio sentido del término [...] (pp. 35-38).

La civilización en la encrucijada sostiene que el proceso de automatización "elimina completamente la actividad del hombre en la producción directa y la traslada a las etapas preproductivas: a la preparación tecnológica, a la investigación, a la ciencia, a la preparación del hombre".

En términos de lo que aquí está en juego, las frases clave son las que he marcado con cursivas en ambas citas. Esta obra contiene una respuesta, sumamente elaborada y muy consistente, al dilema arriba planteado sobre las posibilidades de la des-alienación y, por tanto, del florecimiento humano. Después de haber expuesto la "naturaleza de la revolución científico-técnica”, Richta et al. abordan sus consecuencias sociales y humanas. Caracterizan el trabajo simple, que formó la base de la civilización industrial en la cual "el trabajo está separado del hombre, [como] mera necesidad externa, simple medio de una existencia cuya razón de ser está fuera del propio traba-

\footnotetext{
${ }^{27}$ Arizmendi aborda la teleinformática y la biotecnología como armas de dominación del capital, pero no analiza los efectos en el carácter del trabajo humano que se derivan de la automatización.
} 
jo". Se apoyan en la siguiente frase de Marx: "La abstracción de la categoría 'trabajo,' 'trabajo general', trabajo sans phrase, punto de partida de la economía moderna”, para añadir tajantemente: "se convierte en una realidad práctica en la producción industrial clásica en cadena. En ella, el 'trabajo abstracto'... se erige, sin mediación alguna... como una 'abstracción real'”. Dado que el trabajador no se puede realizar en el trabajo en tanto que ser en desarrollo, sus intereses y obligaciones se forman en el exterior del trabajo, en la esfera del consumo, pero el tiempo disponible se convierte en una ilusión ya que "A menudo, al trabajo embrutecedor corresponde un ocio del mismo tipo" (cita de J. Dumazedier, pp. 128-130). Y añaden brillantemente, distinguiendo necesidad interna de externa:

[...] en tanto el trabajo no sea una riqueza para el hombre, será al contrario la riqueza la que se convierta en el móvil del trabajo. Por el hecho de que la actividad socialmente útil en forma de trabajo no constituye para los hombres una necesidad interna, sino solamente una necesidad de subsistencia externa (eventualmente una obligación social), las necesidades del hombre están manifiestamente contenidas en la esfera privada (p. 130).

Establecido este duro diagnóstico del carácter del trabajo en el sistema industrial, La civilización en la encrucijada mira hacia lo necesario para una solución duradera y afirma que sólo la superación del conjunto de las condiciones fundamentales de trabajo en última instancia, la reducción y la modificación sensible del trabajo industrial, es la llave de los cambios sociales y técnicos, y sin ellos el círculo de la civilización contemporánea queda cerrado. Miran entonces hacia dentro, hacia el socialismo que les tocó vivir:

Las formas materiales del socialismo se fundan, esencialmente, en el trabajo tal como está constituido en el sistema industrial, al que hereda. Aunque el hombre socialista, en función de la modificación de las condiciones sociales, mantenga objetivamente una relación diferente con el trabajo (actúa como una verdadera parcela del gobierno global) [... no por ello es menos cierto que reaparece en otro plano el desgarramiento interior [...] a consecuencia de los límites industriales del trabajo [...] el hombre no se realiza en él [...] como un ser creador, en desarrollo; no lo siente como una necesidad directa; no encuentra en él un enriquecimiento; en él no vive $[. .$.$] Es por esto por lo que la sociedad socialista$ no podría acomodarse a los límites abstractos del trabajo heredados del desarrollo industrial (pp. 131-132).

Richta et al. no sólo afirman que algunos aspectos de la alienación siguen presentes en el socialismo de los sesenta (palabras marcadas en cursivas), sino que además proporcionan testimonios directos de trabajadores al respecto. De ahí derivan la fuerte tesis de que el socialismo es incompatible con el sistema industrial (palabras subrayadas).

Pero la revolución científico técnica abre la gran esperanza, puesto que mientras que el "tipo predominante de obrero en la producción industrial mecanizada es el del obrero-operario manejando máquinas o atrapado en el engranaje de la cadena, o eventualmente el peón que llena los poros del incompleto sistema de máquinas" (p. 133), la automatización compleja va cada vez más lejos [...] liberando al hombre de su participación directa en el proceso de producción [...] de su papel de simple 'engranaje' en el sistema de máquinas y le ofrece, como contrapartida, el de promotor, creador y dirigente del sistema técnico de producción" (p. 135). Esta gran esperanza es descrita como realización en el trabajo:

Podemos esperar que el proceso de la revolución científico-técnica hará, en primer lugar, desaparecer el trabajo de ejecución (hombre que sirve al mecanismo), para atacar inmediatamente después a la actividad de regulación y de control [...]; es decir, absorberá el trabajo industrial simple tradicional [...] que no constituye una necesidad para el hombre, sino que viene impuesto por una necesidad externa. Por otra parte, una vez que el hombre cesa de producir las cosas que las mismas cosas pueden producir en su lugar, se abre ante él la posibilidad de consagrarse a una actividad creadora que movilice todas sus fuerzas [...] que tienda a la investigación de vías nuevas, a la expansión de sus capacidades. La difusión general de este tipo de actividad humana marcará de hecho la superación del trabajo [...] En efecto, una vez que las formas materiales de la actividad humana le dan el carácter de manifestación activa de sí, la necesidad externa, determinada más bien por la necesidad de subsistencia o por la obligación social, cede su lugar a la necesidad interna del hombre; en ese momento, la actividad hu- 


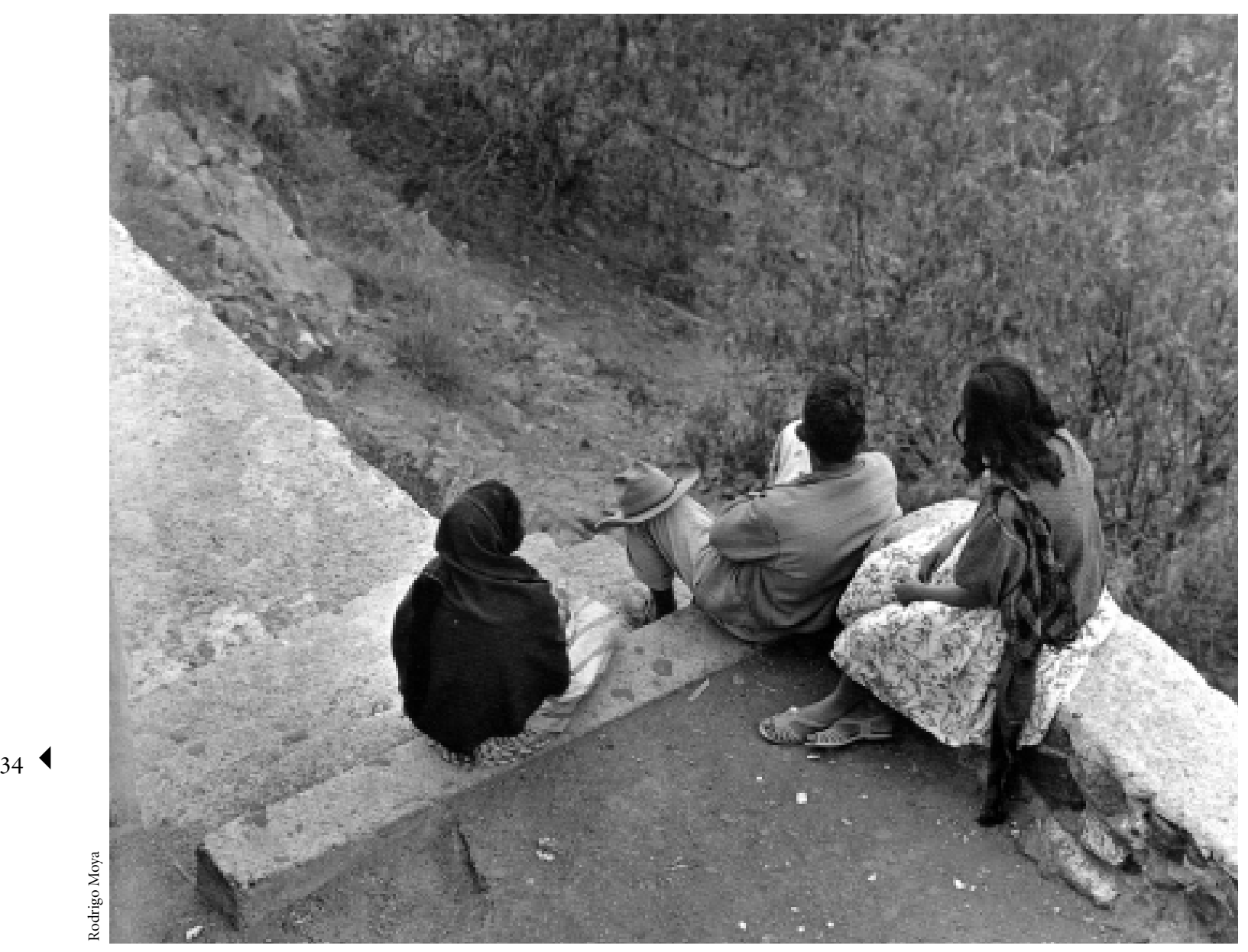

Peñón de los Baños, ciudad de México, ca. 1965.

mana se convierte en una necesidad del hombre, que existe para sí y le enriquece; entonces desaparece la contradicción abstracta entre el trabajo y el placer, entre el trabajo y el tiempo libre: la actividad humana se confunde con la vida.

Sólo se operará el desplazamiento del trabajo humano hacia una actividad creadora (una vez reunidas las condiciones sociales que le puedan servir de base) si se modifican las formas materiales de la actividad humana, si la manifestación activa de sí del hombre reviste un carácter científico y adquiere cualidades estéticas; dicho de otro modo, si se supera la contradicción entre medios y fines que minaba el trabajo industrial, si la actividad humana, por sus cualidades para el hombre, convierte simultáneamente el fin en medio y el medio en fin (pp. 136-137).
En cuanto a la generalización futura de la revolución científico-técnica, en el capitalismo y en el socialismo, $L a$ civilización en la encrucijada sostiene su incompatibilidad básica con el capitalismo y su correspondencia básica con la tarea central del socialismo:

El mundo capitalista aceptará el proceso de transformación del trabajo mientras se desarrolle sólo en algunos talleres, algunas empresas o algunos sectores, mientras no tome proporciones universales y pueda compensarse con el crecimiento del trabajo industrial en otros sectores [...] [En Estados Unidos] la dudosa hipótesis de que los cambios en el trabajo no serán tan amplios y rápidos como los podría permitir la revolución científico-técnica, y que por ello no pondrán 
en tela de juicio el funcionamiento del 'sistema industrial', es la esperanza (y el argumento de base) de los informes oficiales. Si era preciso dar alguna prueba de que la revolución científico-técnica se implanta espontáneamente en ese sistema no habría otra más definitiva. ¡Qué paradoja [...] mantener la utilización industrial del hombre cuando la técnica permite abolirla! Se quiere preservar, 'en interés de los hombres', el trabajo simple tradicional [...] con una 'política activa, moderna y estatal, que se oriente a compensar las consecuencias de los cambios técnicos por artificiales procesos de industrialización extensiva. La alienación que reside en el trabajo es, de este modo, llevada al límite de lo absurdo: los hombres, preocupados por no convertirse en superfluos, mantienen el nivel de trabajo que sus propias fuerzas creadoras hacen cada vez más superfluo. El sistema industrial tradicional les ha reducido de tal manera a la condición de simple fuerza de trabajo, que se identifican ellos mismos con tal condición; el trabajo que les limita, que les abruma, que les quita la vida, les parece ser la única garantía de una existencia libre, e incluso de la misma vida [...].

El problema cardinal de las revoluciones contemporáneas y la misión civilizadora propia del socialismo es comenzar la transformación general del trabajo humano. El concepto de Marx y Engels de la 'superación del trabajo' distingue profundamente su humanismo del de todos sus predecesores $[\ldots]$ (pp. 138-142).

Es decir, volviendo a nuestra discusión previa, en opinión de este grupo de autores para superar la alienación del trabajo son necesarias tanto las transformaciones en las relaciones sociales de producción como en el carácter del trabajo humano. La alienación en el tiempo libre habrá desaparecido, según Radovan Richta et al., quienes, en plena coincidencia con Toti, sostienen que el carácter creativo del trabajo humano que la revolución científico-técnica ofrece como promesa eliminará la contradicción entre tiempo de trabajo y tiempo libre. Es evidente, también, que el camino del florecimiento humano tiene que apoyarse en la revolución científico-técnica, que ya no es ciencia ficción sino una realidad palpitante. También es clara la vigencia del materialismo histórico: la tesis central de la contradicción entre el desarrollo de las fuerzas productivas y las relaciones sociales de producción se manifiesta ahora de manera aguda en la incompatibilidad entre el desarrollo de las fuerzas productivas, que llevan a la automatización total, y las relaciones capitalistas de producción. En efecto, al nivel más abstracto y lle- vando el asunto a los extremos, el sistema salarial, esencia del capitalismo, se comprime brutalmente con la automatización total porque los robots no perciben salarios ni necesitan consumir. Si el valor generado se distribuyese solamente entre el capital y la mano de obra muy calificada que éste tendría que seguir empleando, no habría suficientes compradores a quienes vender los bienes producidos, que podrían crecer exponencialmente. El desarrollo de las fuerzas productivas compatible con el capitalismo parece estar llegando a su fin. La globalización, la expansión industrial hacia el tercer mundo, para capturar la muy barata y dócil mano de obra, parecen salidas temporales que esconden dicha contradicción.

Con el artículo de Damián termina la serie de cuatro artículos que forman parte de la sección Saberes y Razones, misma que cierra con el comentario de Paulette Dieterlen titulado "Cuatro enfoques sobre la idea del florecimiento humano". Su comentario no se restringe a los artículos que hemos analizado hasta ahora, sino que incluye también los demás contenidos temáticos del número: los trabajos de Márkus y Levitas en las secciones Testimonios y Legados, así como la reseña de Des Gasper sobre el libro más reciente de Martha Nussbaum. Por ello, lo presento al final.

\section{MIRADA A LA TEORÍA CRÍTICA}

Este número de Desacatos se ve muy honrado al poder incluir el capítulo final (y central) del libro de György Márkus Language and Production. A Critique of the Paradigms, en la sección Testimonios. Por las dificultades que la inclusión de una obra así entraña, fue necesario que la traducción estuviese precedida de una presentación que, independientemente de mis intenciones originales, terminó siendo básicamente un resumen de los capítulos previos ( 1 a 4 ) de la parte II, referida al paradigma de la producción, de dicho libro. En lo que sigue me limito a enumerar los problemas del materialismo de Marx identificados por Márkus en el capítulo 3 del libro, para después narrar el hilo conductor del texto traducido.

En el capítulo 1 de la parte II de su libro, Márkus ha presentado el materialismo de Marx como proyecto ra- 
dical de transformación práctica; en el capítulo 2 ha desarrollado lo que puede llamarse las 'reglas de la vida': reglas (técnicas) de uso y normas (sociales) de empleo, cuya formulación significa un avance muy sustancial del materialismo de Marx; en el capítulo 3 ha problematizado la distinción entre estas reglas, mostrando su interpenetración práctica y ha concluido que su distinción plena es materia central del proyecto socialista; en el mismo capítulo Márkus asume una postura muy crítica de las tendencias del pensamiento tardío de Marx, sobre todo en El capital. En primer lugar, identifica el carácter teleológico de la visión de la historia, no en el sentido de perspectivismo (punto de vista pragmático sobre una posible transformación radical), sino en el sentido de un finalismo directo. Mientras más la posibilidad de una transformación radical de la sociedad capitalista tomaba la forma de una tendencia histórica objetivamente necesaria, más la noción de socialismo adquiría un significado finalista. Este finalismo resolvió, en principio, el problema metodológico al proveer la justificación para la distinción entre lo técnico y lo social en épocas caracterizadas por la interpenetración de ambas esferas, pues el socialismo, al dividirlas, hace directamente real lo que era abstractamente verdadero. Pero el costo de esta respuesta es muy alto: la distinción entre 'contenido material' y 'forma social' se transforma así en la distinción entre 'esencia' y 'apariencia'. La dialéctica hegeliana es reinstalada. En segundo lugar, identifica cómo este finalismo afecta todo el paradigma de la producción de dos maneras interconectadas: lleva a la 'naturalización' del contenido material y hacia la 'fenomenologización' de la 'forma social'. En tercer lugar, a la tendencia a la naturalización del contenido corresponde la de describir los mecanismos e interconexiones del modo de producción como 'fenómenos superficiales'. Las diferencias en el tratamiento de la competencia entre los Grundrisse (donde es todavía la "naturaleza interna del capital, su naturaleza esencial") y $E l$ capital (donde pasa a ser parte de la esfera de las apariencias) ilustran esta tendencia. Aquí Márkus advierte que éstas son sólo tendencias compensadas por otras señaladas antes, lo que enfoca su crítica a la ambigüedad del pensamiento de Marx. En cuarto lugar, el elemento central del paradigma de la producción, la conceptualización de ésta como unidad de dos procesos - el proceso técnico del trabajo como objetivación de necesidades y capacidades, y el de la reproducción (y cambio) de las relaciones socioeconómicas como 'materialización' de una forma social, la relación dialéctica entre fuerzas productivas y relaciones de producción - enfrenta también una ambigüedad inherente pues surge la duda sobre los criterios para distinguir entre la división técnica (parte de las fuerzas productivas) y la social del trabajo (parte de las relaciones sociales de producción). En quinto lugar, el proyecto práctico de una sociedad que superaría la reificación al separar institucionalmente la administración de las cosas de la auto-administración de las personas lo transforma en una utopía remota, pues sólo puede ser realizada en una sociedad en la que prevalezca la absoluta abundancia. De aquí concluye que el paradigma de la producción llega a un callejón sin salida, pues la perspectiva que requiere para justificar en teoría la separación —un proyecto de sociedad que institucionaliza la distinción de los dos tipos de constituyentes (contenido material/forma social) — resulta irrelevante para los fines práctico-críticos de la teoría. Este desmembramiento de los momentos teórico y práctico del paradigma significa su desintegración en general. En sexto lugar, la extensión ilimitada de necesidades humanas, postulada por el paradigma de la producción como central a la historia humana, que aprehende este proceso histórico también como la creación de la posibilidad de adquirir control colectivo-social efectivo sobre sus determinantes a través de la organización consciente voluntaria de las relaciones sociales, sigue siendo una noción problemática (puesto que es poco claro si la presuposición de un dinamismo ilimitado de necesidades permite un estado de 'completa abundancia' aún como una posibilidad abstracta), entonces toda la construcción se tambalea. La unidad de la concepción de un dinamismo teórico con una noción inmanente de la racionalidad práctica social se cae en pedazos.

En el capítulo final de su libro, titulado "Sobre la posibilidad de la teoría crítica”, aquí traducido, György Márkus aborda "algunos de los problemas y de las consecuencias generales" de su intento de radicalizar el paradigma marxiano de la producción, como salida teórica a las serias dificultades de éste que ha identificado y que he enu- 
merado en el párrafo anterior. La radicalización consiste en interpretar las distinciones básicas del paradigma ("fuerzas productivas/relaciones de producción") como distinciones práctico-históricas en sentido radical: relativas siempre a un proyecto histórico-social asociado a las necesidades e intereses de agentes particulares.

La primera aplicación de esta radicalización la lleva a cabo Márkus en relación con la distinción entre lo inevitable 'exterior' (al cual hay que adaptarse) y lo inevitable generado por los mismos hombres (que la actividad colectiva puede 'deshacer'), respecto de la cual sostiene que es una distinción que sólo los actores mismos pueden hacer para distinguir hasta qué punto su propia actividad debe ser 'reproductiva' y en qué medida puede ser 'creativa', y qué tienen que hacer para que su actividad social sea consciente. Este principio general lo aplica a la distinción fuerzas productivas/relaciones de producción, respecto de la cual Márkus pone en duda la idea de Marx de que las fuerzas productivas son los 'frutos de civilización' a los cuales 'el hombre nunca renuncia', y que lleva al paradigma de la producción a establecer una supuesta conexión empírica entre la idea teórica de la continuidad histórica y la idea valorativa de progreso. Márkus concibe la pretensión del paradigma de constituirse en la ciencia real, positiva, del desarrollo humano como altamente problemática. Sostiene que la idea del carácter irrenunciable de los frutos de la civilización, entendida como generalización empírica es falsa, y como postulado de racionalidad práctica se contrapone a otros análisis del propio Marx que implican que lo que es objetivamente un 'progreso' de las fuerzas productivas bajo un sistema puede aparecer como una 'regresión' en otro. Por ello plantea el siguiente dilema: O bien uno identifica 'las fuerzas productivas' con alguna noción preestablecida de técnica y tecnología, y en este caso en tiempos de grandes transformaciones las fuerzas productivas adquiridas pueden ser 'objeto de renuncia y abandono' (lo cual implica renunciar al vínculo entre su desarrollo y la noción de continuidad histórica, vínculo constitutivo de todo el paradigma marxiano). O bien, la noción misma de fuerzas productivas ha de definirse a través de la continuidad histórica: como aquellos elementos subjetivos y objetivos de la riqueza social a cuyo uso productivo los individuos no 'renuncian' porque constituyen para ellos una precondición necesaria de la vida. En una sociedad en la cual fuerzas sociales opuestas luchan por alternativas distintas, la lucha ideológica se articula parcialmente en torno a esta definición. A esta pluralidad ideológica de diversos grupos sociales, Márkus añade la pluralidad de las propias teorías críticas que buscan llevar a determinadas fuerzas sociales a la 'conciencia de sî', al entendimiento de sus propios intereses y necesidades 'reales'. Ambas pluralidades son hechos normales de la vida ideológica. Por lo dicho, la vinculación marxiana directa de las nociones de continuidad y de progreso histórico mediante el concepto de desarrollo de las fuerzas productivas es, según Márkus, insostenible.

Márkus reformula en los siguientes términos las relaciones entre los conceptos de continuidad y discontinuidad: el paradigma de la producción (a través de las nociones de objetivación y apropiación) concibe la continuidad como rasgo inmanente constitutivo de la historia porque la vida humana sólo es posible mediante la apropiación de resultados previamente objetivados, pero la apropiación es selectiva y rebasa la preservación: hereda el pasado dominando sus resultados de acuerdo con las necesidades del presente. La discontinuidad supone un cambio en los criterios de selección mediante los cuales los sujetos se apropian y reproducen activamente los 'productos' del pasado. La discontinuidad existe en la historia como cambio de dirección de la continuidad histórica. Márkus introduce, por tanto, el elemento valorativo y sostiene que es imposible 'inferir' el progreso de la continuidad empírica de la historia porque la idea de progreso se refiere a una continuidad definida de valores entre un futuro entendido dinámicamente y su 'pasado' inmediato. Márkus sostiene que la pretensión de Marx de otorgar validez universal a la solución del socialismo al describir la historia humana como proceso contradictorio de creación y acumulación de valores que sólo pueden alcanzar su 'pleno florecimiento’ en él parece funcionar sólo gracias a una construcción y estructuración previas del tiempo histórico en función de valores ya elegidos. Por tanto, Márkus concluye que la fidelidad al historicismo radical del paradigma de la producción obliga a renunciar a este procedimiento circular. La teoría del progreso humano no es 
la 'ciencia positiva' de la historia. Sólo tiene sentido como parte del esfuerzo histórico práctico para darle a la historia humana el significado de progreso: crear condiciones bajo las cuales todos los individuos puedan participar de manera efectiva e igual en las decisiones para vivir mejor, de acuerdo con sus propios valores y necesidades. $\mathrm{Al}$ formular este objetivo, la teoría marxiana del socialismo lleva a cabo una elección de valores. No hay garantías metahistóricas ni del 'éxito' de esta empresa, ni de su deseabilidad, concluye Márkus, añadiendo que el proyecto radical del socialismo marxiano si bien no puede ofrecer pruebas indubitables de su justeza, se funda en la evidencia, experimentada vivencialmente, de lo injusto del estado presente de cosas.

Márkus continúa preguntando qué tanto afecta la referida radicalización al significado del concepto de contradicción entre fuerzas productivas y relaciones de producción, cuya intención, en la teoría madura de Marx, es la de conectar las condiciones objetivas, que hacen posible la transformación social radical, con las fuerzas sociales capaces de llevarla a cabo. En este contexto Márkus analiza el sentido del enunciado de Marx: "la mayor fuerza productiva es la propia clase revolucionaria”, a partir del argumento central de las últimas obras de Marx: las disfunciones de la economía capitalista que se traducen en una amenaza constante a los niveles de vida elementales de los trabajadores generan en ellos inevitablemente motivaciones radicales que trascienden el sistema, y que son idénticas a la aspiración 'natural' de cada individuo a garantizar la satisfacción de sus necesidades básicas 'elementales'. Pero hace notar que la presuposición de un sujeto exclusivo, único y unitario de la transformación revolucionaria reduce la gama de motivaciones radicales posibles que queda así reducida a una negatividad abstracta, pues del proletariado sólo se puede afirmar que le caracterizan aquellos 'móviles' que están dirigidos contra el capitalismo, pero faltan entonces motivos a favor de una sociedad socialista. Si el vínculo entre las condiciones objetivas y las intenciones radicales se establece por medio de la noción de 'intereses objetivos', la teoría crítica debe hacer del socialismo la alternativa única, teleológicamente predeterminada, al capitalismo. La concrescencia paradójica del determinismo y el finalismo en la teoría de la 'reificación' de $\operatorname{Marx}^{28}$, que él elabora al mismo tiempo que la comprensión 'negativista' de las motivaciones radicales y que la interpretación 'cientificista', constituyen la constelación teórica más elaborada y coherente hasta hoy de la teoría crítica ${ }^{29}$.

Pero Márkus considera que esta versión de la teoría de Marx en El capital entra en conflicto con intenciones más generales de sus trabajos tempranos que implican una comprensión radicalmente nueva de la intersubjetividad como objetividad social externa que 'determina' y trasciende a los sujetos (seres limitados y finitos porque lo que son y pueden ser está delimitado por 'circunstancias sociales' heredadas). Sin embargo, son ellos los únicos sujetos de la historia porque toda la objetividad social es su creación y sólo tiene sentido humano-social en relación con sus prácticas. Esta noción de intersubjetividad supone una concepción de 'sujeto' en la que se unifican la autonomía y la finitud humanas.

Esta concepción quedó intacta con la transformación más importante de la teoría marxista, el reemplazo tácito del proletariado como vehículo único de la revolución por la humanidad encarnada en el mundo de los valores y las objetivaciones culturales, que Márkus atribuye al Lukács tardío y a varios autores de la Escuela de Frankfurt. La consolidación de la sociedad neocapitalista hizo que la perspectiva de una revolución basada en la

${ }^{28}$ Para el análisis de la teoría de la reificación de Marx por parte de Márkus, véase la sección referida al capítulo 3 en mi presentación de su ensayo en este mismo número de Desacatos. En esencia, la reificación consistiría en la "coalescencia de las relaciones sociales con la relación humana práctica con la naturaleza”.

${ }^{29}$ Márkus identifica los Grundrisse como el único escrito en el que Marx formula una concepción de "motivaciones positivas" para el cambio radical (intenciones y necesidades radicales cuyo contenido trasciende el capitalismo), pero sostiene que este escrito presenta rasgos utópicos, ya que las 'motivaciones positivas' se basan en la perspectiva de un desarrollo industrial inevitable que tecnológicamente elimina, al final, la distinción entre trabajo físico e intelectual, entre tiempo de trabajo necesario y libre. La transición de los Grundrisse a El capital, problemática en otros aspectos, significa mayor coherencia teórica y una comprensión más realista del presente y sus tendencias, concluye Márkus. Es claro para el lector de esta presentación que la visión de Radovan Richta en este punto es radicalmente opuesta a la de Márkus, pues aquél ve en la revolución científico-técnica la realización de estas predicciones de Marx, aunque probablemente no suscribiría el rasgo de inevitabilidad. También es claro que Márkus utiliza aquí el término utópico en sentido derogatorio. 
inseguridad de la simple subsistencia se volviera irrelevante para las realidades de las sociedades occidentales desarrolladas. El pensamiento marxista entró en un periodo de 'búsqueda del sujeto’ que conlleva la disolución de la construcción teórica que le permitía articular y justificar su pretensión de validez, dice Márkus. La posibilidad de la teoría crítica volvió a ser una cuestión; la "crisis" del marxismo se hizo abierta y explícita.

La 'radicalización' del paradigma de la producción que, para superar sus inconsistencias, propone György Márkus significa partir de los problemas teóricos y las exigencias prácticas del presente para reconstruir las 'intenciones originales' de Marx: el significado objetivo de su 'ruptura' con tradiciones teóricas anteriores. También significa que la precondición 'trascendental' de la posibilidad de la teoría crítica es la realidad empírica 'vivida' de necesidades radicales que, en su contenido, trascienden el presente y apuntan hacia una nueva organización social $^{30}$, y también condicionan el contenido conceptual de la teoría puesto que la distinción entre 'condiciones materiales' (fuerzas productivas) y 'relaciones sociales' sólo se puede trazar en función de dichas necesidades: las primeras son los elementos sociales que, en relación con las necesidades formadas por la historia, representan una precondición necesaria de la vida humana, una objetividad indiscutible (no valorativa); mientras las segundas (que regulan la reproducción de dichos elementos) pueden ser cambiadas y por ello tiene sentido cuestionarlas.

La teoría crítica puede volver imaginable un futuro alternativo, dando así voz a la miseria muda del presente $y$ transformándola en aspiraciones radicales conscientes ${ }^{31}$, sos-

\footnotetext{
${ }^{30}$ Márkus se refiere aquí a Teoría de las necesidades en Marx (Península, Barcelona, 1978) de su amiga Ágnes Heller (ambos fueron alumnos de György Lukács en Budapest y se exiliaron juntos en Australia en 1978), pero advierte que hay diferencias entre la postura de ambos. Márkus reconoce su deuda intelectual (respecto a las intenciones originales de Marx) con Max Horkheimer, figura central de la Escuela de Frankfurt, cuya corriente de pensamiento se conoce como teoría crítica. Lamentablemente sólo se refiere a escritos tempranos de este autor sin proporcionar las referencias.

${ }^{31}$ Note el lector la semejanza de esta frase con muy diversas expresiones de parte de Ruth Levitas referidas al papel del pensamiento utopista. Nótese en particular el paralelismo entre la "educación del deseo" y la transformación de la "miseria muda del presente" en "aspiraciones radicales conscientes".
}

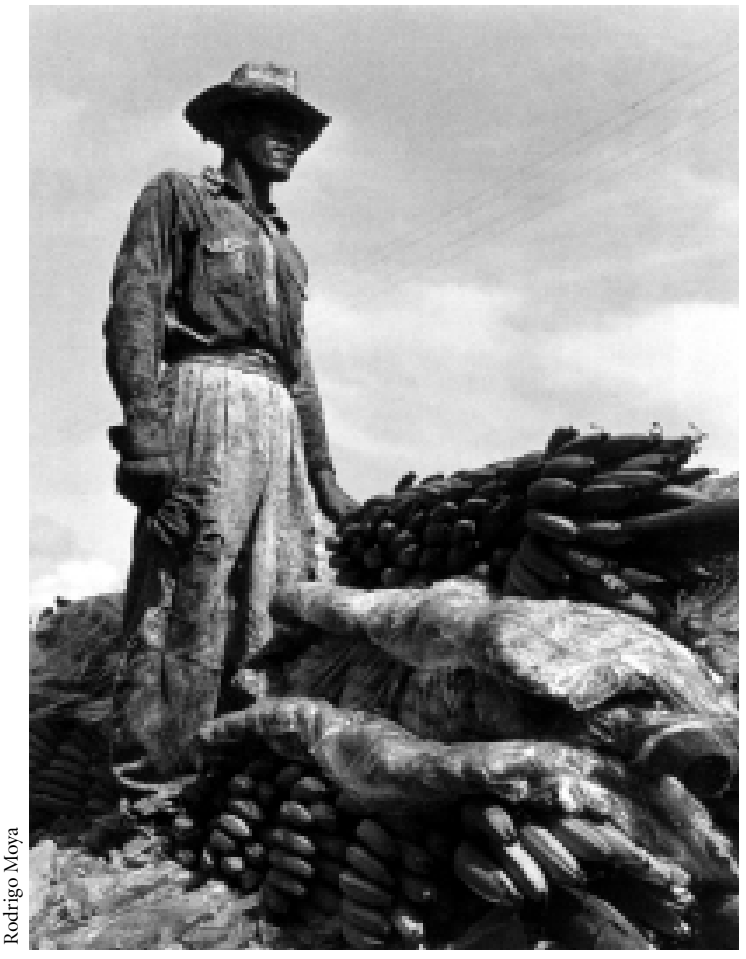

Panamá,ca. 1964.

tiene el autor. La radicalización de la teoría modifica el argumento sobre la pretensión de validez de la teoría, concebida ahora por Márkus como una apuesta a la continuidad y a la fecundidad del diálogo, al "proceso de aprendizaje" y ya no a la inmutabilidad de una 'doctrina verdadera'. Pero no es menos ambiciosa ni menos universalista: La teoría crítica como atalaya del historicismo radical de la finitud humana, dice Márkus, al analizar el presente desde el punto de vista de una alternativa de futuro basada en necesidades radicales definidas, ha de probar su carácter universal: su capacidad de conducir la unificación práctica del género humano. Pero en vez de la unicidad del sujeto radical acepta la posibilidad de su pluralidad inevitable. Si la pluralidad de valores se plantea como valiosa en sí misma, entonces la unidad del género humano ya no se puede pensar ni bajo la categoría de un agente único de transformación radical ni bajo la noción de un consenso alcanzado (que una teoría única pudiera prefigurar en abstracto); se tendría que entender como diálogo ininte- 
rrumpido, basado en la solidaridad práctica y la tolerancia creativa, entre diferentes culturas y formas de vida ${ }^{32}$.

En lo que resta del capítulo, Márkus reflexiona sobre la filosofía y sus conceptos básicos de manera magistral. Disfrútenlo. En todos los aspectos discutidos la teoría crítica se encuentra en una situación que no es la superación sino más bien la realización abierta de las antinomias de la filosofía. Márkus señala y continúa argumentando que la filosofía empieza cuando se distingue entre hechos y normas y su relación se convierte en un proble$m a$. Que su historia es la de intentos constantes para reformular esta distinción como para construir una relación entre los conceptos así distinguidos. Que su 'fin' acontece cuando se deja de considerar que las relaciones entre naturaleza y convenciones, objetos y valores, hechos y normas, ciencia y moral, constituyen un problema significativo. Que la filosofía sólo puede sobrevivir si se asume como actividad pura que nos recuerda algo que ya conocemos en la práctica de la vida —el entretejimiento indisoluble de los 'hechos' y las 'reglas' como fundamento incuestionable de la racionalidad humana.

Márkus cita la siguiente frase de Marx: "desarrollar, a partir de las formas presentes de la realidad existente, la realidad verdadera como su deber y su fin último", y comenta que esta declaración programática temprana suena no como la abolición sino más bien como la reafirmación de la pretensión tradicional de la filosofía. 'Contenido material' $y$ 'forma social', estos dos conceptos que expresan respectivamente las relaciones del hombre con la naturaleza y las relaciones entre hombres como opuestos, son una conceptualización más ofrecida por Marx para trazar la línea entre lo que sólo puede ser explicado en cuanto a sus causas y utilizado, por un lado, y por el otro lo que, en principio, puede ser objeto de decisión y que se puede defender o derribar.

$\mathrm{Al}$ articular esta distinción dentro del 'paradigma de la producción', Marx propone una solución al problema filosófico relativo a 'naturaleza' y 'convención,' 'hechos' y

\footnotetext{
32 Esta discusión tiene múltiples relaciones con la discusión que lleva a cabo Des Gasper sobre las tentativas de Nussbaum de postular su lista como compatible con el pluralismo. El pluralismo de Márkus parece más radical que el de Nussbaum.
}

'normas', que trasciende la 'unilateralidad' tanto de las 'filosofías de la comunicación' como del positivismo, señala Márkus al concluir su importante libro. El paradigma de la producción sostiene la unidad indisoluble de hechos y reglas en la constitución del mundo vital como realidad material humana. Y no sólo en el sentido de que cada objeto hecho por el ser humano es simultáneamente una objetivación de relaciones pasivas y activas del hombre con la naturaleza (necesidades y capacidades) y una materialización de formas sociales definidas, sino también porque las nociones de objetivación y de materialización presuponen, ambas, la noción de reglas sociales. La distinción que tiene sentido hacer no es entre hechos desnudos y reglas desencarnadas derivadas de convenciones, sino entre dos elementos, dos constituyentes de la factualidad social, ambos co-constituidos mediante reglas, pero de distinto tipo: reglas 'técnicas' y reglas en sentido estricto sociales. Pero esta distinción es siempre relativa al momento histórico, a la situación vital de los sujetos sociales que la trazan. Lo que desde un punto de vista socio-histórico definido sería un simple hecho o una necesidad técnica puede ser visto, desde otra perspectiva, como expresión y afirmación de una elección específica de valores. Pero al mismo tiempo es preciso distinguir y contraponer las exigencias $y$ necesidades de la naturaleza a la esfera en la cual se pueden dar elecciones humanas ${ }^{33}$. La acción racional sólo es posible si uno puede distinguir, por un lado, entre sus condiciones y los medios disponibles que se han de tomar en cuenta y utilizar, y por el otro, los objetivos y fines que han de elegirse y tratar de alcanzar. Cuando la actividad social deja de ser dirigida por la tradición, cuando su carácter poiético (creativo) se vuelve un problema consciente, surge entonces la tarea de establecer esta distinción de manera sistemática, general y justificada. Llega entonces el tiempo de la filosofía. Pero una vez que eso está hecho, que las esferas del physis (hechos) y el nomos (normas) quedan diferenciadas, no hay manera de encontrar

\footnotetext{
${ }^{33}$ Márkus, en esta frase, afirma la distinción entre naturaleza y cultura en contra de la postura de Levitas examinada supra. Pero de manera más fundamental nos hace ver, en el texto que sigue, que sin esta distinción no es posible saber dónde puede el ser humano intervenir. Toda acción racional se volvería imposible.
} 
una conexión lógica válida entre las dos. No sólo es imposible deducir 'debe' de 'es', tampoco se puede inferir de un 'contenido material' dado su 'forma social'.

Ahora bien, concluye Márkus, ni el uso óptimo de los recursos disponibles para fines dados, ni una jerarquía fija de fines, proporcionan criterios de racionalidad para la actividad de cambio radical que pone en tela de juicio los móviles y propósitos dominantes. La actividad poiética (creativa) sólo puede ser racional si puede encontrar un nexo válido entre hechos y normas, medios y fines. El marxismo es un intento de articular una nueva idea de "razón" que define la racionalidad como una praxis social mediante la cual los hombres pueden hacer una conexión consciente entre medios y fines. Si los individuos, conscientes de las exigencias y limitaciones de su situación vital, a través de la articulación y de la confrontación dialógica de sus necesidades, determinan de manera solidaria los propósitos y los valores de sus propias actividades, entonces su vida es racional. La teoría crítica de la sociedad analiza aquellas condiciones sociales que hoy hacen imposible la realización de esta racionalidad. La teoría crítica ofrece una respuesta al problema sempiterno de la filosofía, al señalar que las antinomias que ella engendra sólo se pueden resolver en la práctica social. Pero la teoría sólo puede ofrecer esta respuesta bajo la forma de un proyecto de reorganización social radical como necesidad y potencialidad de la etapa histórica actual. En este sentido sigue siendo sólo una filosofía. Sólo se propone articular las condiciones bajo las cuales la vida puede ser transformada ahora en tarea válida, a la medida de los seres humanos. Pero sólo puede 'evocar' a los sujetos capaces y dispuestos para tal tarea. Que la tarea sea o no emprendida en la realidad, termina Márkus, no será un juicio sobre la humanidad, sino sobre la 'verdad' y la 'justeza' de la teoría.

\section{MIRADA PROSPECTIVAY RETROSPECTIVA}

En The Concept of Utopia, Ruth Levitas analiza las ideas de diversos autores en relación con el utopismo, entre ellos: Marx, Engels, los socialistas utópicos, George Sorel, Karl Mannheim, Ernst Bloch, Herbert Marcuse y Wi- lliam Morris. En la sección Legados se ha traducido el capítulo 5, "La educación del deseo: el redescubrimiento de William Morris" (en adelante Mirada prospectiva y retrospectiva). En la introducción, Levitas señala que la relación entre marxismo y utopía también es examinada, como en la obra de Bloch, en las discusiones sobre Morris; que los dos intentaron integrar el marxismo y el romanticismo; que comparten el interés en la superación de la alienación y la centralidad del arte. En la primera sección hace un breve esbozo biográfico de Morris, en el que destaca su rechazo estético inicial al capitalismo y la influencia de John Ruskin (romántico radical y notable crítico de arte), que lo llevó a escribir sobre las relaciones entre producción artística y fundamento social; relata su papel en organizaciones socialistas, sus conferencias sobre socialismo, y se refiere a su novela A Dream of John Ball. Pero la sección se centra en la obra más conocida de Morris, la novela utópica News from Nowhere (1890), situada en la Inglaterra del siglo XXII, que pinta una sociedad artesanal desmonetizada, en la cual ha desaparecido la distinción entre el campo y la ciudad, no hay escuelas, no hay parlamento, y la separación entre trabajo manual e intelectual ha sido superada. "Es mucho más que una ficción reaccionaria y medievalista", concluye Levitas. Explica que la escribió como respuesta a la novela utópica de Edgard Bellamy, Looking Backward, que retrata una sociedad socialista centralizada. Morris publicó una crítica de ella y la "contra-imagen del socialismo que ahí expone debe leerse como la intención subyacente de News from Nowhere", dice Levitas. Dicha crítica ratifica que lo central para Morris era la transformación del trabajo, que es el corazón mismo del socialismo, concluye Levitas y, en la siguiente sección, "Arte, trabajo y alienación", ahonda en la idea del trabajo como placer, para que éste "asuma su debido papel como el terreno de la autorrealización humana — es decir, en la superación del trabajo alienado".

Sostiene que el enfoque de Morris respecto a esta superación es más auténticamente marxista que el de Bloch "porque se concentra en la transformación del proceso de trabajo y en la abolición del mercado que lo gobierna”. Para ambos autores, añade, la superación de la alienación involucra al arte; pero mientras Morris, como artista crea- 


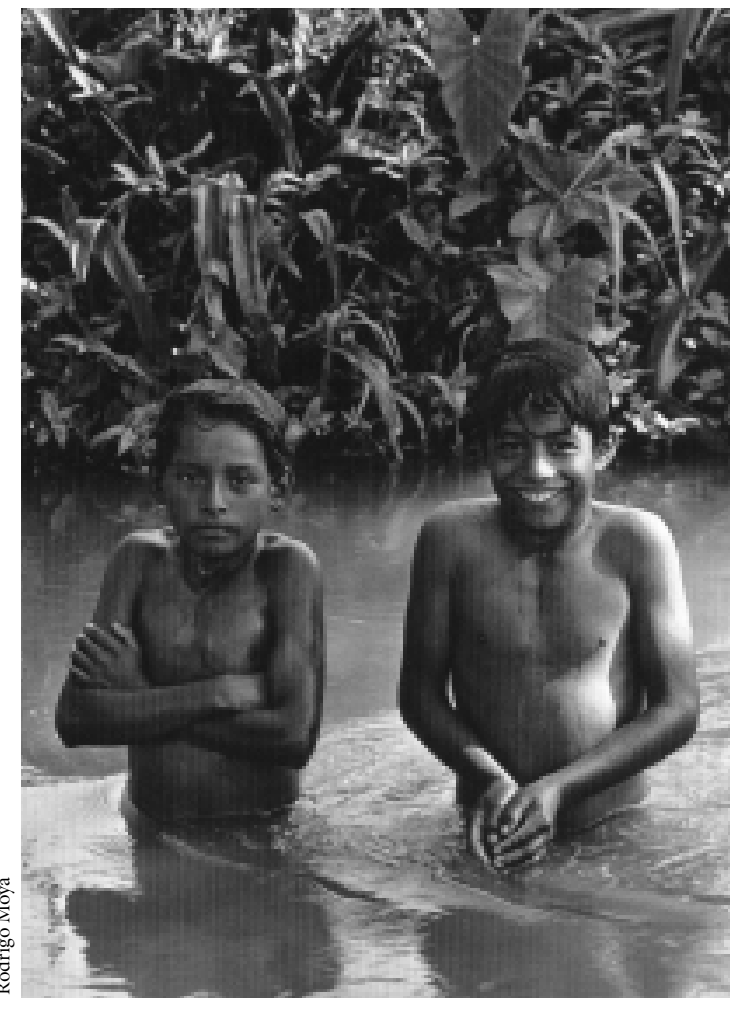

Morelos, ca. 1964

tivo que era, ve el papel de la creación artística, Bloch, como crítico cultural, ve el lado receptivo, la experiencia del momento de plenitud, pero es el que atribuye al arte la función utópica más activa, mientras Morris no le atribuye un papel activo directo en la realización de la utopía.

La siguiente sección de Mirada prospectiva y retrospectiva empieza a explorar la reconsideración de la obra de Morris que vino a contrarrestar dos mitos que se propagaron en los años que siguieron a la publicación de News from Nowhere, que lo tildaban de burgués o de menchevique antimarxista. Relata cómo la rehabilitación de Morris comenzó con la publicación de tres libros en los cincuenta: el de A. L. Morton, The English Utopia, que ve a News from Nowhere como la culminación de una tradición utópica que habría arrancado 500 años antes y presenta la novela como el resultado de la lucha de clases, como el comunismo acabado, lo que para Levitas conlleva la creación de otro mito, pero opuesto. El segundo es el de E. P. Thompson, William Morris: Romantic to Revolutionary, que atribuye a Morris la síntesis entre marxismo y romanticismo que enriquece a ambos y califica la novela como una "utopía científica", pero este libro fue ignorado por los marxistas. El tercer libro es Culture and Society, de Raymond Williams, que sostiene que Morris derivó de Ruskin una comprensión correcta de qué tipos de trabajos son buenos para los hombres, los elevan y los hacen felices y la había aplicado a las nuevas circunstancias; pero este juicio se basó en sus escritos políticos y se formó a pesar de News from Nowhere, por su nostalgia regresiva. Levitas comenta que la rehabilitación de Morris (por parte de Thompson y de Williams) no implica una rehabilitación de la forma utópica novelesca, pero sí una rehabilitación de la función utópica, del arriesgarse a ir más allá, que es una característica de sus escritos políticos.

La sección "Reivindicaciones y contra-reivindicaciones" arranca con el análisis de la edición de 1977 del libro de E. P. Thompson, que contiene un postscriptum en el cual el autor debate con dos académicos franceses que escribieron importantes obras sobre Morris. Thompson arremete contra el mito que asimila al marxismo tal cual toda la obra de Morris, como se manifiesta en La pensée utopique de William Morris, de Paul Meier, en el cual se sostiene que la crítica al capitalismo, la transición y los detalles de la sociedad proyectada son idénticos a los implícitos en Marx. Levitas coincide con algunas de las objeciones que le hace Thompson, como la subestimación de la importancia de la tradición romántica. Pero la objeción principal es que Meier fortalece la división dicotómica entre romanticismo y marxismo que Morris había superado.

La sección "Soñar el futuro" pone de relieve la función heurística y axiológica de la utopía en contraste con la función sistemática que busca diseñar maquetas detalladas de una sociedad futura. Levitas retoma ideas de Bloch y de J. Goode sobre la forma de sueño de los escritos de Morris y la conciencia anticipadora que expresan, cuya función utópica última es transformar la realidad. Goode percibe que Morris "insiste en una estructura completa de valores y perspectivas". La autora aborda la obra de Miguel Abensour sobre Morris a través del análisis de E. 
P. Thompson ${ }^{34}$. Éste coincide con la idea de que la importancia de News from Nowhere radica en la exploración de valores y que su propósito "es corporizar, en las formas de la fantasía, valores alternativos esbozados en un modo de vida alternativo", pero cuyo meollo no es ofrecer un modelo de sociedad sino subvertir el presente. Aquí Levitas cita las ideas de Abensour que dan título al capítulo:

en una aventura así, el sentido común de la sociedad burguesa cae en desorden y entramos al espacio propio y novedoso de la utopía: la educación del deseo [...] se trata de enseñarle al deseo a desear, a desear mejor, a desear más y sobre todo a desear de manera distinta.

Levitas complementa lo anterior al decir que News from Nowhere "nos invita a experimentar lo que significaría estar en plena posesión de nuestra humanidad —una experiencia que, según Bloch, nos proporcionan las obras de arte en el 'momento de plenitud'35. Levitas refiere las conclusiones a las que llega E. P. Thompson en su Postscriptum: 1) el marxismo tardío apagó las facultades de imaginación utópica y recayó en el utilitarismo del crecimiento económico; 2 ) "reivindicar a Morris puede permitir reivindicar al utopismo mismo para que recorra el mundo de nuevo sin vergüenza"; 3 ) el marxismo (reino del conocimiento) y la utopía (reino del deseo) son complementarios y se necesitan mutuamente, lo que coincide - añade Levitas — con la idea de Bloch de las corrientes caliente y fría del marxismo, la corriente de la pasión y la del análisis.

En la sección "Forma, función y contenido", Mirada prospectiva y retrospectiva discute la presencia de estos tres

\footnotetext{
${ }^{34}$ Ruth Levitas no da la referencia bibliográfica de la obra de Miguel Abensour. Se trata de su tesis de doctorado. E. P. Thompson, en el famoso Postscriptum, la consultó como tesis, pero hace referencia a su planeada publicación como libro con el título de Utopies et dialectique du socialisme, Payot, París, probablemente en 1977. El título de la tesis es "Les formes de l'utopie socialiste-communiste" y es tesis de doctorado de estado en ciencia política de París-I, 1973.

${ }^{35}$ Son varias las asociaciones con otros elementos discutidos a lo largo del presente número de Desacatos: la educación del deseo y el desarrollo de las necesidades son claramente ideas cercanas; la realización humana y el florecimiento humano son conceptos gemelos, y los momentos de plenitud son similares a las experiencias cumbre que Maslow sostiene que todos podemos experimentar y que nos muestran, en ese momento, lo que es la autorrealización.
}

elementos de la utopía en la obra de Morris. En cuanto a la función de la utopía, ésta conlleva la postulación de una escala de valores radicalmente distinta, que permite un "salto fuera del reino de la necesidad hacia un reino de libertad imaginado, en el cual el deseo puede realmente indicar elecciones o imponerse como necesidad", dice Thompson citado por Levitas, quien concluye de manera brillante que si "la función de la utopía es la educación del deseo, la función de la educación del deseo es la realización de la utopía". Levitas cita un ensayo de Raymond Williams en el que éste sostiene que la utopía se distingue, por el elemento de transformación deliberada, de la ciencia ficción, en la cual la transformación surge de un cambio tecnológico o del cambio de las circunstancias ${ }^{36}$. La autora añade que la preocupación por el cambio característica de los análisis marxistas presenta el mismo problema ${ }^{37}$. Lo que le parece valioso a Williams en la utopía de Morris es, añade Levitas, el "reconocimiento del largo proceso de desarrollo de nuevas necesidades, condiciones y relaciones sociales"38. Mirada prospectiva y retrospectiva continúa analizando las diferencias entre utopías sistemáticas y heurísticas, transformadoras (emancipatorias) y compensatorias, abstractas y concretas. Las distinciones entre las funciones negativas y positivas de la utopía, anota Levitas, suelen remitir al tercer aspecto bajo examen, el de contenido. El término utópico se usa en sentido peyorativo para imágenes del futuro que, por su contenido o por su incapacidad de explicar la posibilidad de la transición, carecen de poder de transformación. Aborda la visión de Morris sobre las limitaciones y el peligro de la utopía destacando la conciencia de Morris de que: "Es imposible construir un esquema para la sociedad

\footnotetext{
36 Se abriría aquí, pero Levitas no lo hace, el tema del cambio tecnológico y la utopía, que la autora analiza muy poco y que, como vimos en la sección "Una mirada esperanzadora", el cambio tecnológico derivado de la revolución científico-técnica es elemento central en las posibilidades de superación del trabajo alienado, sin lo cual un elemento negativo central del capitalismo no podría ser superado excepto a costa, como en Morris, de una vuelta a la tecnología pre-industrial. ${ }^{37}$ Aquí tendríamos que añadir la sorpresa de no encontrar en Márkus un análisis de la revolución científico-técnica y la ausencia de cualquier referencia a la obra de Radovan Richta.

${ }^{38}$ Resulta interesante que Williams hable del desarrollo de necesidades en Morris y no de la educación del deseo.
} 
del futuro pues nadie puede de verdad sustraerse mentalmente de su propio tiempo". Puesto que la utopía es especulación sobre el futuro socialista, su función en el mejor de los casos es apoyar la transición hacia este futuro; en el peor, impedirla involuntariamente. Por ello es necesario distinguir entre buenas y malas utopías, sujetar el deseo a la disciplina (Thompson), separar la utopía abstracta de la concreta (Bloch). Las obras de Thompson y Bloch han debilitado el tradicional rechazo marxista a la utopía. Las funciones educativa y transformadora de soñar, transformación cuyo objetivo es superar la alienación, el papel del arte tanto en prefigurar dicha experiencia (Bloch) como en su realización (Morris), son todas pretensiones de la utopía que si no estuvieran contenidas en el marxismo son al menos compatibles con él y son su complemento indispensable, concluye Levitas.

La última sección de Mirada prospectiva y retrospectiva, "Marxismo, romanticismo y utopía", es básicamente la confrontación de las conclusiones a las que ha llegado con un planteamiento crítico de Perry Anderson. Pero aquí me interesa, sobre todo, destacar algunas ideas de
Levitas más que las críticas de Anderson. Levitas señala que lo que Anderson objeta con más fuerza es la categoría de deseo y rechaza la frase "enseñar al deseo a desear..." como irracionalismo. Levitas comenta que la frase objetada, si bien puede no ser irracional, es claramente no racional y añade algo de la mayor importancia: "todo el problema es que las categorías 'racionales' de conocimiento y análisis no pueden contener la experiencia humana y que también hay que tomar en cuenta sus aspectos no racionales, pero distinguir entre no racional e irracional puede ser difícil". Continúa Levitas este excelente texto de la siguiente manera: "El énfasis en la experiencia y el sentir, común al momento de plenitud de Bloch, al éxtasis milenarista de Mannheim, a la educación del deseo de Abensour y a la posesión heroica del yo de Sorel, en efecto entraña peligros reales [...] Pero tanto Thompson como Ernst Bloch reconocen claramente el problema: es la razón por la cual la utopía no sólo es asunto de expresión y búsqueda del deseo, sino que entraña su educación". Volviendo a Anderson, observa que le parece más interesante la tesis de éste de que "la polarización entre el pensamiento y el sentimiento también está histó- ricamente determinada: la distinción entre los principios operativos del deseo y el conocimiento reitera así la antítesis entre romanticismo y utilitarismo [...] para Anderson el avance real sería la superación de este conflicto". Ante la acusación de romanticismo a la que están expuestos Morris, Thompson, Abensour, Goode y Bloch, responde que el anticapitalismo romántico fue una fuente esencial no sólo del compromiso revolucionario de Morris sino del de Marx, y el concepto de alienación permite enlazar el análisis de las estructuras económicas con la experiencia humana. En el párrafo final de Mirada prospectiva y retrospectiva señala que la relación problemática entre marxismo y utopía no depende de la pregunta de si deberíamos pensar el futuro, sino de cómo deberíamos pensarlo y, en particular, cómo habría que pensar sobre los sentimientos y la experiencia. Que el problema del marxismo versus la utopía se manifiesta de dos maneras: 1) como un problema del utilitarismo $v s$. el romanticismo (Löwy y Anderson sostienen que Marx superó esta antítesis; Thompson sostiene que lo hizo Morris); 2) del conocimiento $v s$. el deseo y de la corriente fría $v s$. la caliente (pensamiento vs. sentimientos); Thompson y Bloch proponen una relación dialéctica entre ambos, sin alcanzar una síntesis, que sería siempre frágil.

\section{MIRADA AMPLIA DEL ENFOQUE DE NUSSBAUM}

Cuando empecé a planear este número de Desacatos invité a Martha Nussbaum a colaborar en él. Muy amablemente se excusó por no poder hacerlo dada su agenda, pero sugirió que el número incluyese una reseña de su nuevo libro, Frontiers of Justice, lo que me pareció excelente. Nunca dudé que la mejor persona para hacer dicha reseña era Des Gasper, quien afortunadamente aceptó y ahora me toca presentar su amplio y muy profundo ensayo sobre el enfoque de Nussbaum, enfoque que también es comentado en este número por Paulette Dieterlen en su discusión, y en Crítica de la EPP. Des Gasper, en su ensayo titulado "La ética del desarrollo humano y las Frontiers of Justice de Martha Nussbaum" (en adelante Mirada amplia del enfoque de Nussbaum) se refiere al 
enfoque de esta autora a veces como ética del desarrollo humano, o perspectiva integral o teoría del desarrollo humano, y a veces como enfoque de capabilities, aunque aclara que este nombre le queda corto, y que quizás el más adecuado sería humanismo cosmopolita, con el subtítulo de enfoque de capabilities. Des Gasper adopta una visión amplia del enfoque de Nussbaum, pues sostiene que ver sólo algunos aspectos (sólo la lista de capabilities humanas centrales, por ejemplo) resultaría artificial y podría conducir a conclusiones erróneas. Por ello intenta poner en claro la variedad de propósitos y la correspondiente gama de métodos utilizados por la filósofa estadounidense; aborda además los principales debates en torno a su enfoque y cómo ella ha ido respondiendo a las críticas y modificando su enfoque; evalúa los métodos recomendados por Nussbaum, su compromiso con un amplio espectro de elementos de evidencia, y analiza el discurso de cosmopolitismo ético de Nussbaum.

Gasper empieza señalando que el enfoque de Nussbaum no se reduce (como el de Sen) a la evaluación de ventajas y su distribución, sino que como teoría del desarrollo humano debe abordar otros propósitos: entender la conducta y explicar la capacidad de actuar (agency), para movilizar la atención, el interés y el compromiso; y para orientarnos en los procesos de formular decisiones. Define seis áreas esenciales en el trabajo sobre desarrollo humano (especificación de los valores éticos que deben definirlo y conducirlo; sus causas y obstáculos; la operacionalización del enfoque, incluyendo la medición; un programa de investigación y de acción; una base de amplio compromiso e interés públicos; amplia observación y evidencia) y sostiene que la visión integral de Nussbaum incluye casi todas esas áreas interconectadas. Enumera lo que a su juicio involucra su enfoque: una lista de prioridades específicas para las vidas humanas; una manera de percibir con apertura y afinidad; la utilización de una amplia y rica gama de evidencias, que incluye la ficción, la poesía, las autobiografías, las entrevistas abiertas y la observación; una comprensión más profunda, que usa ricas imágenes de la mente, del concepto de persona, de las emociones y del lenguaje; y un estilo de presentación que explora el sentido humano de esa evidencia.

Para Gasper, en contraste con el enfoque más delgado de Sen, la ética de Nussbaum habla en términos de gente real y proporciona una rica imagen de lo que es una vida humana plena. Sus trabajos del periodo 1988-1995 generaron cortocircuitos en el debate que se buscaba desarrollar, debido a un estilo aristotélico demasiado enfático. En cambio, estima que en sus dos libros más recientes, Las mujeres y el desarrollo humano y Frontiers of Justice, se ofrece una presentación integrada y práctica, más profunda y más mesurada, argumenta. En ellos lo nuevo está constituido por "el duro razonamiento práctico del derecho"; su adopción del liberalismo político rawlsiano que no impone una ética exhaustiva en particular, sino que abre las opciones; los resultados de sus visitas periódicas de investigación a la India; la incorporación del comunitarismo sin caer en el relativismo; y la demostración de que hay posibilidades para la variación cultural al poner en operación las capabilities centrales. Viene enseguida un comentario de Gasper que resulta paradójico en este número de Desacatos dedicado al florecimiento humano: señala con aprobación que Nussbaum busca ahora, más que una lista exhaustiva de requerimientos sugeridos para el florecimiento humano, especificar los criterios de un "mínimo social decente" con base en un conjunto limitado de capabilities más básicas en contraste con una más larga lista de functionings requeridos que había propuesto antes para una buena vida humana. "La versión más reciente, dice Gasper, contiene un enfoque intermedio más útil, como le aconsejaron varios comentaristas [...] el sentimiento fuertemente aristotélico, combativo, del norte, ha declinado considerablemente". Bajó la mirada y se le aplaude, en nombre del consenso y de evitar la percepción de imperialismo cultural pero, como veremos, el costo puede ser muy alto, lo que el propio Gasper, paradójicamente, hará notar más adelante.

Mirada amplia del enfoque de Nussbaum señala que la lista de capabilities prioritarias de Nussbaum debe ser entendida como un método y en términos de sus roles subyacentes; que Nussbaum se dirige a identificar una lista ampliamente consensuada o convincente de capabilities (oportunidades) de prioridad universal. Aunque la lista está abierta, según la autora, al debate y la reelaboración, a la interpretación local y al establecimiento de umbrales, es necesaria porque sin un conjunto arraigado de 
necesidades dejamos el asunto demasiado abierto a la interpretación por parte de los que detentan el poder. La lista proporcionaría un punto de partida y fundamento para una carta de derechos, como parte de una constitución política, y descansa en la expectativa de que sus resultados convergerán con los de un criterio de deseo informado. Note el lector que con la palabra informado, Nussbaum se deslinda de las preferencias (que suelen ser no informadas). En opinión de Gasper, mientras el criterio que aplica Nussbaum — ¿qué constituye una vida humana decente? - permanece un tanto vago y su aplicación, intuitiva, y la lista parece un poco artificiosa, Doyal y Gough utilizan criterios más precisos, y un método más explícito y estructurado que opera hacia atrás a lo largo de una cadena causal ${ }^{39}$. Nussbaum formula la lista diciendo que resulta siempre racional querer todas las capabilities humanas centrales al margen de cualquier otra cosa que uno quiera. Gasper ataca esta formulación con el ejemplo de la sexualidad de los religiosos célibes, respecto de los cuales Nussbaum ha insistido que ellos racionalmente desean las oportunidades sexuales pues es solamente así que su abstinencia adquiere significado. Con el argumento de la no universalidad, Doyal y Gough dejaron fuera de las necesidades intermedias el "sexo con otras personas". Al respecto comenté en Ampliar la mirada: "este criterio es demasiado restrictivo y provoca que las minorías (por ejemplo, los célibes) impongan restricciones a los demás." También subrayé la contradicción entre excluir el sexo e incluir la necesidad intermedia "control natal y partos seguros", asociada al sexo (vol. I, p. 240), como necesidad intermedia universal. Gasper adopta la postura de Doyal y Gough y le plantea a Nussbaum establecer un criterio más restringido y preciso, como el de Doyal y Gough, o bien trabajar el criterio más amplio y vago de la decencia humana y quedarse sólo con

\footnotetext{
${ }^{39}$ Se refiere al libro A Theory of Human Need de Len Doyal e Ian Gough (Macmillan, Londres, 1991). Gasper especifica la cadena 'causal', sin embargo, introduciendo erróneamente los conceptos de Sen y Nussbaum (functionings y capabilities) como si hubiesen sido asumidos por Doyal y Gough, cuando en realidad éstos adoptan los siguientes cuatro niveles: precondiciones societales, necesidades intermedias, necesidades básicas y objetivo universal. Para un análisis detallado y crítico de este importante libro, véase el capítulo 6 de Ampliar la mirada.
}

las capabilities más centrales (como afiliación y razón práctica) y quizás algunas más, mientras los demás serían elementos deseables pero no requerimientos absolutos. Es decir, le sugiere reducir la lista y además la exhorta a reconsiderar un papel menos protagónico para la misma, para que "los elementos valiosos del enfoque integral de capabilities" no sean "puestos en peligro por la reducción del enfoque a una búsqueda de una especificación perfecta de este elemento indicativo".

El cosmopolitismo ha sido un tema clave en el trabajo de Nussbaum, señala Des Gasper, quien en Frontiers of Justice sostiene que existen debilidades básicas en el enfoque del contrato social de John Rawls porque marginan o ignoran a los discapacitados, al no humano y al débil, y vincula este aspecto con los pobres de todo el mundo, creando una perspectiva cosmopolita. Deslinda el cosmopolitismo ético, fundamentado en visiones de que uno podría relacionarse con las personas alrededor del mundo como compañeros humanos iguales, y que consiste en un trato igualitario a la gente de todo el mundo y en obligaciones éticas más allá de las fronteras nacionales (solidaridad) — que es lo que defiende Nussbaum y que es un cosmopolitismo liberal—del político, el cultural y el sociológico. Sin embargo, no todas las variantes del cosmopolitismo liberal son liberadoras, como cuando los principios de la moral global son las leyes del libre mercado, comenta Gasper.

Para identificar qué es lo nuevo en materia de cosmopolitismo en Frontiers of Justice, hace notar que el tema unificador del libro es la crítica a la teoría del contrato social, incluso en la versión más avanzada, que es la de John Rawls, por su incapacidad para proporcionar justicia a los grupos más débiles. Para ello explica algunos rasgos de la teoría de la justicia de Rawls, mostrando la serie de fronteras que establece y que significan la exclusión de los discapacitados, los animales no humanos y los desposeídos de otros países. Estos son los tres temas que constituyen las fronteras de la justicia que dan sentido al libro de Nussbaum. Gasper enumera cuatro novedades del libro: 1) la crítica sistemática de la teoría del contrato social (TCS); 2) la afiliación categórica al enfoque de derechos humanos; 3 ) mayor claridad en la explicación de la afiliación de Nussbaum al liberalismo político y la aplicación de éste a 
escala global; 4) hace sugerencias programáticas. En cuanto a la segunda novedad, Nussbaum concibe el enfoque de capabilities como una de las especies del enfoque de derechos humanos. Los valores a los que se apela son cooperación social, compañerismo, respeto humano y dignidad. Además se proporciona una base teórica para los derechos humanos, que deben ser entendidos en correspondencia con las necesidades fundamentales, a saber, los requisitos de una dignidad básica, estipulados en la forma de un conjunto de capabilities. Si suponemos que Gasper ha hecho una lectura cuidadosa de Frontiers of Justice, estas frases confirmarían que el enfoque de las capabilities de Nussbaum, igual que el de Sen, no es independiente del concepto de necesidades humanas, como lo hice notar en Crítica de la EPP. En cuanto a la tercera novedad, dice Gasper que Nussbaum extiende el liberalismo político a escala global para respetar la dignidad y la inviolabilidad de cada persona, lo que está lejos todavía de una ética universal y de una concepción del florecimiento humano exhaustivas. La presentación de la cuarta novedad la pospone Gasper para más adelante.

Mirada amplia del enfoque de Nussbaum incursiona a continuación en los roles del enfoque y los métodos que emplea; enumera cinco roles. Señala que su modulado pero franco cosmopolitismo, en el que sostiene círculos concéntricos de intensidad de afiliación decreciente, está vinculado con su método: observar el contenido detallado de las vidas fortalece no sólo el reconocimiento de lo que compartimos, sino también la aceptación emocional de esta humanidad compartida. Añade que la metodología de Nussbaum se centra en la reflexión detallada de casos del 'tamaño de la vida' que involucran de manera reconocible a personas reales, incluyendo las de la creación literaria (que se someten a análisis textual profundo). Describe la gama de sus fuentes: además de los materiales convencionales de filosofía y economía, también la ficción, la poesía, las autobiografías, las entrevistas y la observación directa, y elementos de la ley y la psicología, incluyendo las elecciones prácticas que tienen que encarar jueces y políticos, y el trabajo de campo, particularmente en la India. Continúa analizando cómo se puede derivar "comprensión ética a partir de las narraciones humanistas de densa textura", lo que ejemplifica con Tiempos

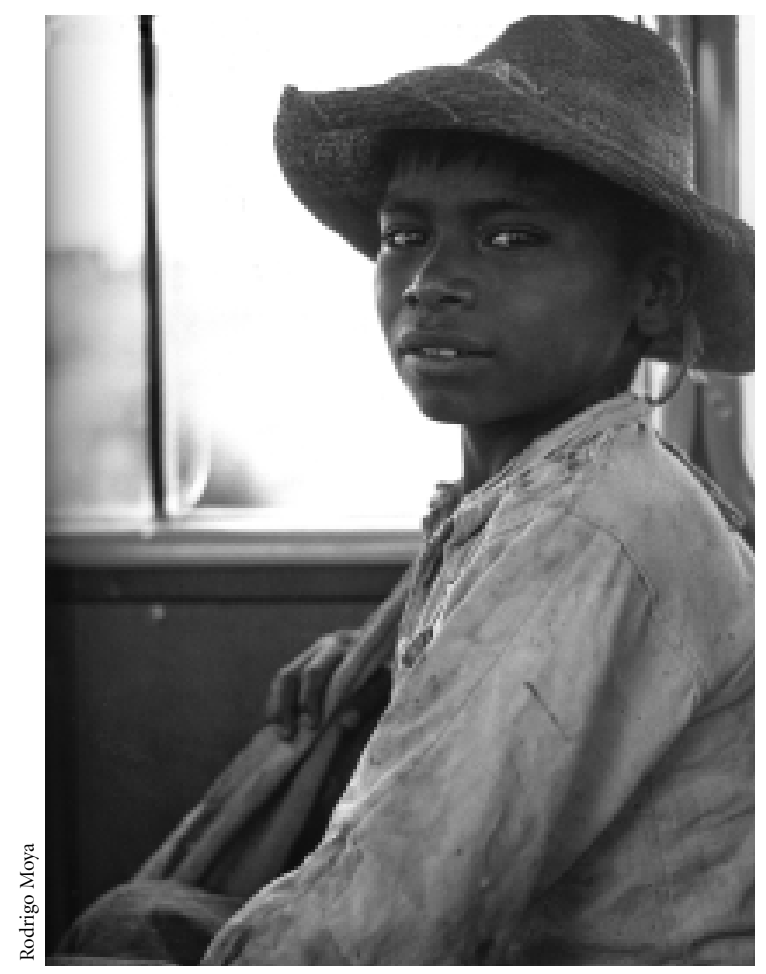

Valle del Mezquital, Hidalgo, 1955.

difíiles de Dickens, analizado con detalle por Nussbaum. Gasper también analiza las ideas al respecto de diversos teóricos literarios.

Mirada amplia del enfoque de Nussbaum destaca otra virtud de dicho enfoque: su atención a las emociones, particularmente a la compasión. Apunta el papel central que la compasión ("preocupación por el infortunio inmerecido de otra persona”) desempeña en la vida moral y, por tanto, en la social, según Nussbaum, quien ahonda en esta emoción, discusión en la que Gasper también interviene, en particular sobre la palabra que he marcado en cursivas. Encuentra que la fuerza retórica de Nussbaum incluye lucidez y sinceridad, que se complementan con su práctica ocasional de una "crítica interna", concepto que en realidad se refiere a un requisito del diálogo con otras culturas. Para influir en una cultura, Nussbaum y Sen han dicho, relata Gasper, que no se puede pedir aceptación de paquetes de ideas 'arrojados en paracaídas', que carecerían de resonancia local, relevancia o aceptación; que lo que 
hay que hacer es construir en gran medida a partir de las fuentes intelectuales y recursos internos de cada cultura. Esta concepción implica que las tradiciones son algo más que un conjunto de prácticas fosilizadas, que contienen subtradiciones de reflexión y el potencial para evolucionar, explica Gasper, y añade que Nussbaum advierte el peligro de que el discurso interno de la ética basada en las tradiciones pueda convertirse en un respaldo etnocéntrico, y la necesidad de insumos críticos externos. En este difícil acto de equilibrio, Gasper critica a Nussbaum por llevar a veces la conciliación con las prácticas locales demasiado lejos (son los costos del consenso a los que me referí antes), como cuando ha justificado que la India no cumpla las leyes de la educación obligatoria y de la prohibición del trabajo infantil.

Mirada amplia del enfoque de Nussbaum vuelve al cosmopolitismo y enumera los aspectos clave que están involucrados en las presunciones del cosmopolitismo, entre ellos: quiénes son los actores; los supuestos acerca de la naturaleza del concepto de persona; y el temor de que el cosmopolitismo represente una agenda de dominación que son de su clase, entendido como un rasgo característico del ser humano, Nussbaum busca desarrollar una concepción de la cooperación social a partir de la idea de los estoicos de que las relaciones humanas forman una serie de círculos concéntricos, pues la capacidad de empatía es más fuerte con personas que ya están cerca de nosotros y se va volviendo más abstracta mientras más se aleja uno de la esfera del "mí y mío". Nussbaum sostiene que hay que crear concentricidad en vez de dibujar la línea y demonizar lo que queda fuera. Gasper, apoyándose en Onora O'Neill, muestra que las transacciones cotidianas implican que reconocemos que los otros son agentes y sujetos, por lo que no es consistente borrar este reconocimiento durante la discusión de las interconexiones éticas. A partir de este argumento Gasper señala que de diferentes interpretaciones de la interacción global se derivan concepciones diversas sobre el cosmopolitismo. Entre éstas destacan las de David Held y Tono Erskine, que perciben un mundo de innumerables comunidades (no territoriales) que se traslapan entre sí: los individuos son miembros simultáneamente de muchas

comunidades, lo que lleva a la tesis del 'cosmopolitismo hincado'. Es decir, concluye Gasper, que necesitamos imágenes de círculos traslapados, no sólo concéntricos. El universalismo de Nussbaum, su proyecto de extender el liberalismo político a escala global, provoca preocupaciones. Gasper relata algunas reacciones.

Una mirada amplia del enfoque de Nussbaum aborda también las dificultades del lenguaje empleado cuando uno se dirige, como lo hace Nussbaum, a públicos diversos. Ante la reacción recurrente de que la visión de Nussbaum es un intento de mandar a otros, Gasper señala que presentar un punto de vista es aconsejar, no mandar; y que si ninguna verdad en potencia puede ser expresada, la reacción habrá bloqueado el enfoque dialógico por el que supuestamente se aboga.

Nussbaum no aboga por un Estado mundial, por la baja probabilidad de que tuviera un nivel decente de rendición de cuentas a sus ciudadanos, por lo cual la estructura institucional a nivel global debe permanecer delgada, dice Gasper y pasa a enumerar los diez principios que ella sugiere para dicha estructura: 1) sobredeterminación de responsabilidades, lo doméstico nunca escapa de ellas; 2) soberanía nacional; 3 ) mucha más ayuda de las naciones ricas; 4) obligación de las corporaciones multinacionales de invertir socialmente, promover las capabilities humanas y buenas condiciones laborales; 5) un sistema económico global justo; 6) una esfera pública global delgada; 7) presión internacional (sic) a favor de los que sufren desventajas; 8) cuidado de los débiles sin dejar toda la carga en las mujeres de la familia; 9) familia preciada pero no sacrosanta; 10) todas las partes deben ayudar la educación. Gasper añade que la asignación de deberes sería ética porque no existe una estructura coercitiva sobre el todo que pueda obligar a ninguna parte a un conjunto definido de tareas. Comenta que el punto central debiera ser el sistema económico global justo; cita a un autor de manera aprobatoria que señala que una globalización emancipatoria equivale a la re-regulación y a contrarrestar la globalización guiada por las corporaciones; cita a otro autor cuyo texto conlleva una fuerte crítica a Nussbaum, que no parece percibir que "la globalización corporativa es fundamentalmente una tendencia centralizadora $[\ldots]$ un mundo controlado por unos cuantos que toman las de- 
cisiones". Es evidente la debilidad, y en algunos aspectos la ingenuidad, de los diez principios, pero estos defectos se ven atenuados cuando Des Gasper aclara que éstos aparecen como una especie de epílogo sin mucho énfasis de Nussbaum, quien de manera justa juzga que éste es el punto donde "el filósofo debe entregar la estafeta al practicante y al científico social".

Para terminar su ensayo bibliográfico, Des Gasper se pregunta sobre las posibles rutas hacia el cambio. Al parecer, la ruta que prefiere Nussbaum empieza por el cambio de valores: los filósofos siembran las semillas, la sociedad civil las disemina y cultiva, y aplica presión en los que toman las decisiones. Gasper señala que algunos comentaristas han hecho notar que el cosmopolitismo desde arriba está vacío sin el cosmopolitismo desde abajo, sin la experiencia real de ciudadanía o compañerismo mundial. Al final, concluye que la unión entre el re-pensamiento y la fuerza de los movimientos sociales es elemento fundamental para el cambio. Mirada amplia del enfoque de Nussbaum termina con unos comentarios conclusivos en los cuales valora de manera amplia este enfoque: señala que sus formulaciones sobre capabilities deben entenderse como una manera de proceder, como un amplio enfoque al desarrollo ético y humano; que busca una influencia de largo plazo en los marcos constitucionales y legales y sobre la cultura política, a fin de apuntalar la compasión, el cosmopolitismo y los derechos humanos, y en cómo la gente escucha, ve y actúa. Su horizonte temporal, señala Gasper, es el largo plazo; su atención a las bases del interés en los otros es relevante para la ética política, dada la extensión del egoísmo; termina diciendo: vemos la pertinencia de su concentración en el análisis y la educación de las emociones, especialmente la compasión.

\section{CUATRO MIRADAS}

Abordo, para concluir, la discusión que, con el título "Cuatro enfoques sobre la idea del florecimiento humano", lleva a cabo Paulette Dieterlen (en adelante, Cuatro miradas). La autora organiza su comentario en cuatro secciones para analizar otras tantas tradiciones que abordan la pobreza, la desigualdad y el florecimiento huma- no: el liberalismo igualitario, las teorías comunitaristas, lo que llama el enfoque de florecimiento propiamente dicho, y el enfoque de Nussbaum. En la primera sección aborda las ideas de Rawls, empezando por explicar de manera muy clara su concepto de bienes primarios. Habría que unir a Nussbaum con Rawls para que el enfoque liberal igualitario se refiera al florecimiento humano, pues si bien, como dice Dieterlen, es "posible interpretar la noción de bienes primarios como aquello que permite que las personas se respeten a sí mismas y sean respetadas por los demás", tanto en términos de la teoría de necesidades de Maslow como de la lista de capabilities de Nussbaum, esta visión se queda corta ante la de la autorrealización y del florecimiento humano. Aborda la crítica de Sen a Rawls por no tomar en cuenta la diversidad humana. Expone brevemente el enfoque de Sen y se refiere a dos críticas a ambos enfoques. La mía, en el sentido de que la noción de capabilities se refiere sólo al aspecto económico del florecimiento humano, crítica que extiende a Rawls, aunque no queda claro si dicha extensión me la atribuye, lo que sería incorrecto.

La otra crítica a ambos proviene de los comunitaristas que Cuatro miradas aborda en la siguiente sección. Éstos han criticado el concepto de persona que se encuentra en el pensamiento liberal porque el sujeto que manejan no está enraizado en una situación empírica, ignorando el contexto social en que se encuentra ${ }^{40}$. La crítica de Walzer al liberalismo relatada por la autora, que niega la posibilidad de formular una única teoría de la justicia es, como la anterior, una crítica relativista que rechaza cualquier generalización sobre los seres humanos. Como señala Des Gasper en su reseña y comenta Paulette Dieterlen, Nussbaum ha evitado el relativismo bus-

\footnotetext{
${ }^{40}$ Héctor Díaz-Polanco, en su libro Elogio de la diversidad. Globalización, multiculturalismo y etnofagia (Siglo XXI, México, 2006) señala que hay dos frentes críticos que confrontan al liberalismo: 1) el de grupos externos distintos al liberalismo, como el marxismo, y 2) un frente interno del propio liberalismo que confronta a los liberales colectivistas con los individualistas. Dice Díaz-Polanco que este frente no es menos fragoroso que el primero (cap. 5). Al parecer, Dieterlen estaría de acuerdo con esta caracterización, ya que después de presentar las críticas de los comunitaristas al liberalismo, añade: "Así, las discusiones filosóficas sobre la justicia distributiva han decepcionado por igual a los pensadores de izquierda y a los de derecha".
} 


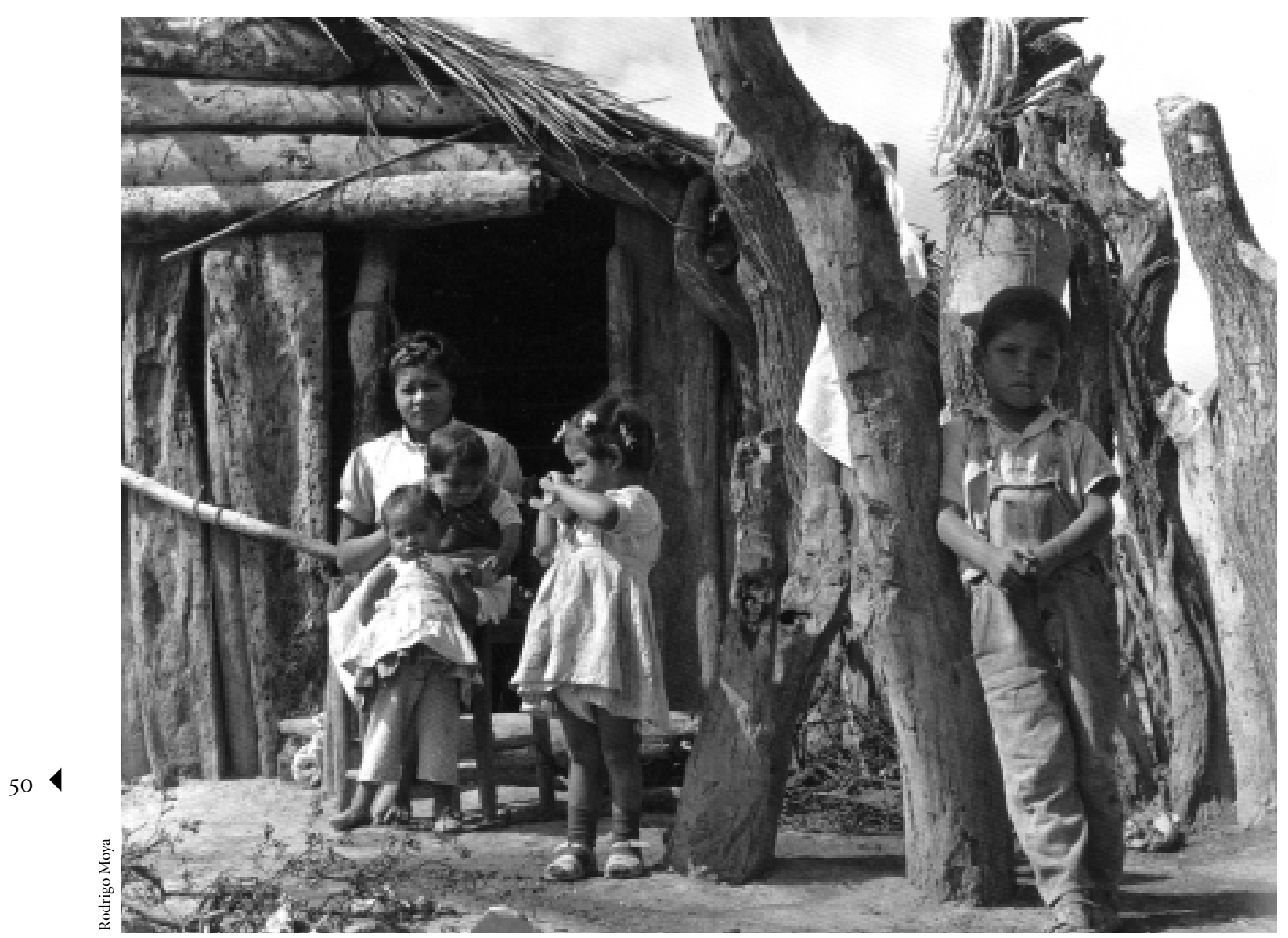

Región ixtlera del norte de México, 1966.

cando un difícil equilibrio entre su postura universalista y los elementos que incorpora del comunitarismo. Dieterlen analiza tres ideas de Charles Taylor: 1) quien contribuye más al bien común merece más (principio de la contribución mitigada); 2) que las sociedades occidentales han valorado de manera independiente los principios de la contribución y el principio republicano (que valora la libertad individual y la capacidad personal de deliberar en comunidad), y que la unión de ambos principios sólo se daría en la medida en que nos acercáramos a una vida comunitaria en la que fueran posibles tanto el autogobierno como la autogestión; 3) lo que estaría en juego es el proyecto de una sociedad diferente. Dieterlen encuentra un punto de unión entre los comunitaristas y los "defensores del paradigma del florecimiento humano": "la visión de las personas como miembros cooperativos de la sociedad".

En la tercera sección de su comentario, la filósofa mexicana agrupa a los autores de este número de Desacatos como defensores del paradigma del florecimiento humano basado en un cambio radical en las instituciones políticas y económicas, lo que es correcto en general, pero no lo puedo afirmar en el caso de Des Gasper. Dieterlen hace una semblanza del fascinante personaje que fue William Morris, y añade que Levitas comparte con Márkus y Boltvinik la idea de que la sociedad capitalista impide que los seres humanos expandan sus potencialidades. La autora comenta que la utopía del tiempo libre a la que 
se refiere Damián consiste en afirmar que sólo si desaparecen las dicotomías analizadas por Marx en Crítica al Programa de Gotha, el "tiempo de trabajo y el libre contribuirán a que los seres humanos se desarrollen y alcancen su más completo florecimiento."

Cuatro miradas pasa a referirse a la cuarta de las miradas: al enfoque de Martha Nussbaum, e introduce el tema de la siguiente manera: "uno de los méritos de la obra de Boltvinik consiste en buscar 'ejes de encuentro' entre diversas tradiciones de pensamiento. Esto lo comprobamos cuando incluye en el número de Desacatos la reseña que hace Des Gasper al último libro de Martha Nussbaum". Dieterlen contrasta la postura de Nussbaum, basada en el liberalismo y el comunitarismo, con la mayor parte de los autores de este número de Desacatos, que ubica "dentro de una tradición fiel al pensamiento de Marx". Por lo que a mí respecta, pero que quizás se pueda también aplicar a Márkus, Arizmendi, Levitas y Damián, la frase estaría perfecta sin la palabra fiel, que puede asociarse con dogmatismo. Como apreciará el lector del texto de Márkus y de mi presentación del mismo, la crítica de Márkus a Marx es muy dura, lo que muestra que la única fidelidad de este autor es con el rigor filosófico. En mi caso, no es tanto que tienda puentes con otras tradiciones sino que, no ubicándome rígidamente en ninguna, estoy abierto a aprender de (casi) todas las tradiciones. Dieterlen dice que:

Boltvinik ha encontrado vasos comunicantes con Nussbaum. Ambos coinciden en el rechazo a reducir el concepto de pobreza a los aspectos meramente económicos y en la crítica que han hecho al concepto de capabilities de Sen. Si bien los dos recurren a la noción de florecimiento humano, Boltvinik reconoce como punto de partida la filosofía de Marx, mientras que Nussbaum se basa en Aristóteles.

Hay mucho que comentar sobre este párrafo. En primer lugar, como podrá apreciar el lector de Crítica de la $E P P$, señalo que "hay una enorme cercanía entre las ideas de Martha Nussbaum y las tesis centrales de Ampliar la mirada". Aunque la crítica explícita de Nussbaum a Sen es mucho más limitada que la mía (se ha concentrado en insistir que Sen debe definir una lista de capabilities centrales), la crítica implícita que, con su propio planteamien- to, le hace a Sen es mucho más amplia, ya que se puede interpretar, por ejemplo, de la clasificación de capacidades de Nussbaum en básicas o innatas, internas y combinadas, que las capabilities de las que habla Sen no son capacidades, aunque no puedo saber si ella estaría de acuerdo con estas afirmaciones. Lo mismo puede decirse respecto a la crítica a Sen por reducir su universo a lo meramente económico. La lista de capabilities de Nussbaum y la inclusión en ella de capabilities como "sentidos, imaginación y pensamiento" que no dependen de bienes económicos, constituye una crítica implícita pero radical a este reduccionismo. Pero cuando uno observa la crítica explícita a la asociación entre bien-estar y recursos, cae uno en la cuenta de que es la misma crítica limitada de Sen: "Los recursos son inadecuados como índice de bien-estar porque los seres humanos tienen requerimientos variables de recursos, y también habilidades variables para convertir recursos en functionings." (Frontiers of Justice. Disability, Nationality, Species Membership, Harvard University Press, 2006, p. 74). Nussbaum no parece darse cuenta de que su lista incluye dimensiones del bien-estar o del florecimiento humano que no se generan con recursos económicos, ni claridad sobre la visión limitada del concepto de recursos de Sen, que excluyen el tiempo y las habilidades/conocimientos (véase el inciso 7.2 de Crítica de la EPP). Por último, tal como lo cito en Crítica de la EPP, Nussbaum, en Las mujeres y el desarrollo humano sostiene que su enfoque está basado en la idea marxista/aristotélica del funcionamiento verdaderamente humano. Es decir, no sólo en Aristóteles sino también en Marx. Es verdad que en escritos anteriores la autora se había proyectado como "aristotelista", por ejemplo, en "Non-relative Virtues: An Aristotelian Approach" (en Martha Nussbaum y Amartya Sen [eds.], The Quality of Life, Clarendon Press, Oxford, 1993, pp. 242-269). Sin embargo, en Frontiers of Justice, como parte de la batalla que tan bien describe Des Gasper para lograr aceptación amplia y multicultural de su enfoque y de su lista, se ha ido deslindando más y más de Aristóteles: "En la medida en la que una idea muy general de florecimiento humano y sus posibilidades está presente en el enfoque no es una sola idea de florecimiento, como en la propia teoría normativa de Aristóteles, sino más bien una idea de un es- 
pacio para diversas posibilidades de florecimiento" (Frontiers of Justice, p. 182).

Dieterlen presenta la lista de diez capabilities humanas centrales de Nussbaum y comenta que éstas están en consonancia con mi postura. No he hecho una evaluación sistemática de la lista, pero en Ampliar la mirada (inciso 11.1) la he comparado con la lista de necesidades de cinco autores y, énfasis más o menos, es correcta en términos generales la asociación de Dieterlen. Termina la sección referida al enfoque de Nussbaum asociando la idea de ésta de educación de las emociones (particularmente de la compasión) con la idea que da título al capítulo del libro de Levitas recogido en la sección de Legados: la educación del deseo, y comentando que la idea de florecimiento humano "incorpora un aspecto emocional muchas veces ignorado por los teóricos de la justicia y los estudiosos de la pobreza”. El desprecio por lo emocional adopta la forma de no consideración de las relaciones como satisfactores de las necesidades humanas, como se muestra en el inciso 7.3, y en el cuadro 2, de Crítica de la EPP.

Para finalizar su ensayo, la filósofa y estudiosa de la pobaum, que sostendría que el florecimiento humano consiste en satisfacer las condiciones objetivas que aparecen en una lista, la posibilidad de un enfoque subjetivo, que se basa en lo que "los seres humanos piensan que necesitan para alcanzar el florecimiento humano", pero advierte de inmediato que este enfoque puede dar lugar a un caso de "preferencia adaptativa", que es la crítica fundamental que Sen ha hecho al utilitarismo ${ }^{41}$. La autora, sin embargo, no toma postura al respecto. Por último, se pregunta si realmente Sen se queda atrapado en una visión economicista de la pobreza. Recuerda el compromiso de Sen con la libertad positiva, cita la definición de Isaiah Berlin y se pregunta si no es ésta una idea muy similar a la de florecimiento humano que defiendo y si, por tanto, Sen, que se basa en ella, queda atrapado en el economicismo. La definición de Berlin es bellísima, pero creo que

${ }^{41}$ Aunque no uso el nombre de "preferencia adaptativa", en Crítica de la EPP señalo que "la adaptación que el pobre lleva a cabo para reconciliarse con su situación significa que puede sentir un gran placer con muy pequeñas cosas, por lo que en la métrica de la utilidad los pobres resignados pueden ser muy eficientes productores de utilidad".

se acerca más a la idea de autonomía que a la de florecimiento humano. La autonomía, y la autonomía crítica, como lo han planteado Doyal y Gough, son condiciones necesarias pero no suficientes para el florecimiento humano. Sen es muy amplio en muchas ocasiones. Es no sólo un destacado economista sino también un destacado filósofo. Pero no es consistente. Atrapado en su necesidad de seguir en la corriente principal de la economía, Sen entra en muchas contradicciones que se reflejan en la larga lista de críticas, casi todas muy severas, que he recogido en la sección 5 de Crítica de la EPP. Creo que el párrafo clave para insistir en que mi crítica a Sen es correcta es el siguiente:

\section{Algunos autores creen que el EC es muy amplio. Pero co- mo se muestra, siguiendo las ecuaciones en Commodities and Capabilities, Sen va mecánicamente de los bienes a los functionings y a la capability. Su universo se reduce a lo que se deriva del consumo de bienes, pero excluye satisfactores como relaciones y actividades. Es una visión de la persona como consumidor (lo contrario de lo que piensa Cohen) pero que parece activo porque Sen le endilga verbos.}

Dieterlen termina su ensayo con un párrafo que resalta la importancia de este número de Desacatos. Cuando se pregunta si encontraremos un sistema político en el que todos podamos ampliar la mirada para concebir la pobreza desde un ángulo diferente, resalta lo que hemos querido destacar con la primera parte del título del número: De la pobreza al florecimiento humano. Hace notar que un eje central del número es la incapacidad del sistema capitalista para generar las condiciones para que los seres humanos alcancen su desarrollo pleno e incluso para que satisfagan las necesidades básicas. Afirma que la intención de los defensores del enfoque de florecimiento humano es que la respuesta a la pregunta sobre si lograremos vivir en una sociedad en la que todos tengamos los medios suficientes para lograr el florecimiento humano, aunque se perciba como utopía, es positiva. Concluye poniendo de relieve uno de los dos elementos de la segunda parte del título (¿Teoría crítica o utopía?): "Lo que este número de Desacatos nos muestra es que no podemos abandonar la utopía si queremos vivir en un mundo mejor". 